В. Я. ПЕТРУХИН

\title{
НАЧАЛО РУССКОГО ГОСУДАРСТВА И ЛЕТОПИСАНИЯ В РОССИЙСКИХ РАБОТАХ 2000-2020-Х ГГ. ${ }^{1}$ \\ THE BEGINNING OF THE RUSSIAN STATE AND CHRONICLES IN THE RUSSIAN WORIS OF THE 2000-2020S
}

The Russian historiographical process of 2000-2020 can be considered as consisting of traditional publishing activity and specifically discussions associated with the celebration of the anniversaries of Old Russian statehood (in 2012), Vladimir the Saint (2015 and the previous anniversary of the baptism of Russia) and the millennium of the composition of the first Russian legal code "Russkaya Pravda”.

Keywords: origin of the Russian state, Rus', the Varangian problem, role of retinue/druzhina, beginning of urbanization, "Russkaya Pravda"

Vladimir Petrukhin - DSc in History, researcher at the Institute of the Slavic Studies at the Russian Academy of Sciences, professor at the Higher School of Economics. Moscow, Russia. E-mail: vladimir.petrukhin@gmail.com. ORCID: https://orcid.org/0000-0002-6151-4262

1 Citation: V. IA. Petrukhin, "Nachalo Russkogo gosudarstva i letopisaniia v rossiiskikh rabotakh 2000-2020-kh gg." [The Beginning of the Russian State and Chronicles in the Russian Works of the 2000-2020s], RussianStudiesHu 3, no. 2 (2021): 89-115. DOI: 10.38210/RUSTUDH.2021.3.15 


\section{В. Я. ПЕтрухин}

Российская историография начала XXI в. опирается как на традиции советской историографии (см. обобщающие труды по историографии, изданные в 1970-е гг.), так и на классическую историографию XIX - начала XX вв. - в первую очередь переиздаваемые (с эпохи «оттепели») собрания сочинений С. М. Соловьева и В. О. Ключевского, которые в постсоветские 1990-е годы были дополнены переизданиями работ А. Е. Преснякова, Н. П. Павлова-Сильванского, П. Н. Милюкова и др., в 2000-е гг. - А. С. Лаппо-Данилевского, М. Ф. Владимирского-Буданова и др. Особым направлением, привлекшим специальное внимание исследователей и издателей в постсоветское время, можно считать «эмигрантскую» историографию, включающую работы Г. В. Вернадского, Е. Ф. Шмурло и др., см. также содержательный обзор Г. В. Вернадского «Русская историография» (Москва: Аграф, 2003) ${ }^{2}$. Доступными стали работы и современных зарубежных исследователей, среди которых специально древнерусской проблематике посвящены труды английских историков С. Франклина и Дж. Шепарда; специальное издание по «американской русистике» содержит работы русистов-медиевистов ${ }^{3}$.

Соответственно, проблемы источниковедения требовали переиздания и переосмысления дореволюционных работ, связанных с проблемами летописания: традиционно российская историография ориентируется на фундаментальные труды А. А. Шахматова (переизданные с академическими комментариями в 2000-е гг.) и его школы (труды по истории летописания М. Д. Приселкова, А. Е. Преснякова) ${ }^{4}$. Переиздается и Полное собрание русских летопи-

2 Работы эмигрантского историка продолжают переиздаваться: Г. В. ВеРнАдский, Древняя Русь (Москва: Ломоносов, 2017 и др.). Содержательную характеристику состояния отечественной историографии древней Руси до начала 2000-х гг. см. в монографии М. Б. Свердлова: М. Б. СвеРдлов, Домонгольская Русь: князь и княжеская власть на Руси VI - первой трети XIII в. (Санкт-Петербург: Академический проект, 2003), 3-39. См. также историографический обзор в кн.: К. А. СоловьЕв, Дело власти: отечественные историки о властных отношениях в Древней и Средневековой Руси (IX - перв. пол. XV вв.) (Москва: МАКС Пресс, 2001).

3 Американская русистика: Вехи историографии последних лет. Период Киевской и Московской Руси (Самара: изд-во Самарского университета, 2001). См. также: А. В. ФЕДОСОВ, КРИСТИАН РАФФЕНСПЕРГЕР, Королевство РУСь. ДревНЯя РУсь глазами западных историков (Москва: Центрполиграф, 2021).

4 См. краткий содержательный обзор: А.В. КАРАВАшкин, Литературный обычай Древней Руси (XI-XVII вв.) (Москва, Санкт-Петербург: Центр гуманитарных инициатив, 2018), 89-119; Т. Л. Вилкул, Летопись и хронограф: Текстология домонгольского киевского летописания (Москва: Квадрига, 2019). См. о других школах: В. Г. ВовинА-ЛЕ- 
сей (ПСРл) с включением (в качестве третьего тома, М., 2000) Новгородской первой летописи (НПЛ) 5 . Переиздание в академической серии «Литературные памятники» «Повести временных лет» (далее - ПВЛ) демонстрирует значимость первого комментированного издания, подготовленного Д. С. Лихачевым в 1950 г. (дополнительные комментарии подготовлены М. Б. Свердловым для издания 1996 г.).

Существенным вкладом в развитие источниковедения остается издание иноязычных источников в специальной серии, поименованной в советский период «Древнейшие источники по истории народов СССР» (инициирована В. Т. Пашуто в 1977 г.); издание («Древнейшие источники по истории Восточной Европы»- в сокращениях) продолжается в отделе истории Восточной Европы института всеобщей истории РАН под редакцией В. Л. Янина и Е. А. Мельниковой. Итоговой стала пятитомная хрестоматия «Древняя Русь в свете зарубежных источников» (ДРЗИ), содержащая переводы фрагментов с комментарием издателей. Наиболее информативным для начальной русской истории является трактат Константина Багрянородного «Об управлении империей», обстоятельное комментирование которого стало возможным в эпоху перестройки (два издания вышли в 1989 и 1991 гг.) ${ }^{6}$. По инициативе Г. Г. Литаврина готовилось 3-е издание, но кончина выдающегося византиниста (2009) прервала его подготовку'.

Спецификой историографического процесса 2000-2020 гг. можно считать традиционную публикационную активность, связанную с

БЕДЕВА, Школы исследования русских летописей: XIX-XX вв. (Санкт-Петербург: Дмитрий Буланин, 2011). Продолжается полемика по поводу «татищевских известий», относящихся к древней русской истории: ср. А. П. Толочко, «История Российская» Василия Татищева: источники и известия (Москва, Киев: НЛО, 2005); А. В. ГоРовенко, Василий Татищев и «древние летописи»: домонгольская Русь глазами первого русского историка (Санкт-Петербург: Изд-во Олега Абышко, 2019).

5 Новое издание было подготовлено М. Б. Клоссом. Интенсивное исследование раннего новгородского летописания продолжается трудами А. А. Гиппиуса, Т. В. Гимона и др.

6 Г. Г. ЛИТАВРИН, А. П. НОВОСЕЛЬЦЕВ (ред.), КОНСТАНТИН БАГРЯНОРОДНЫЙ. Об УПравЛЕНИИ империей. Текст, перевод, комментарий. Изд. 2-е (Москва: Наука, 1991)

7 Вступительная статья Г.Г. Литаврина к новому изданию и отредактированный заново текст и перевод помещены на сайте института славяноведения РАН. «Свод византийских свидетельств о Руси» регулярно пополняется исследованиями М. В. Бибикова: М. В. БиБиков, Bуzantinorossica: Свод византийских свидетельств о Руси. I-IV. (Москва: ЯСК, 2004-2020). Иноязычной лексике трактата посвящена монография: C. Р. ТохтАСЬEВ, Язык трактата Константина Багрянородного Dе administrando Imperio и его иноязычная лексика (СПб: Наука, 2018). 
празднованием юбилеев древнерусской государственности (в 2012 г.) 8 , Владимира Святославича (Святого/Великого) 9 в 2015 (и предшествующим юбилеем крещения Руси $)^{10}$, сложения древнейшего правового кодекса - «Русской правды» ${ }^{11}$.

Исследовательские поиски историков рубежа тысячелетий, будучи освобождены от подцензурного следования советским - марксистским - установкам на формационный подход, обнаружение классов и прочих основ сложения государственности, естественно продолжали и наработки в этой области предшествующей историографии. Наиболее очевидной тенденцией остается поиск свидетельств политогенеза - формирования государственности, предшествующих летописному рассказу о призвании в Новгород варяжских князей (ПВЛ под 862 г.). В качестве источниковедческого обоснования этого поиска обычно используется установка А. А. Шахматова на позднее и искусственное формирование «варяжской легенды».

Поиски глубинных основ славяно-русской государственности вдохновляются тем очевидным обстоятельством, что государственность не могла быть просто привнесена извне (такой наивный взгляд приписывается «норманской теории»)12: восточнославянское

8 СМ.: Б. С. КОРОТКЕВИЧ, Д. А. МАЧИНСКИЙ, Т. Б. СЕНИЧЕНКОВА (редКолл.), Сложение рУСской государственности в контексте раннесредневековой истории Старого Света: материалы Международной конференции, состоявшейся 14-18 мая 2007 г. в Государственном Эрмитаже (Санкт-Петербург: Гос. Эрмитаж, 2009); Н. А. МАКАРов (ред.), Русь в IX-X вв: археологическая панорама (Москва; Вологда: Древности Севеpa, 2012).

9 Н. А. МАКАРОВ, А. В. НАЗАРЕНКо (ред.), РУСь эПохИ ВладимИра ВелИКого: государство, церковь, культура (Москва: Древности Севера, 2017).

10 Б. Н. Флоря (ред.), Христианство в странах Восточной, Юго-Восточной и Центральной Европы на пороге второго тысячелетия (Москва: Индрик, 2002).

11 Т. Е. НовицкАя (ред.), «Историческое правоведение». Вып. 5: Тысячелетие Правды Русской: история и перспективы изучения древнейшего памятника отечественного права: сб. научных трудов (Санкт-Петербург: Президентская библиотека, 2017). См.: также: М. Б. Свердлов, Латиноязычные источники по истории Древней Руси IX-ХIII вв. Германия. «Правда Русская». История текста. Избранные статьи (Санкт-Петербург: Изд-во Олега Абышко, 2017).

12 Анализ стереотипов «борьбы с реакционной норманской теорией» был предпринят с позиций ленинградской археологической школы Л. С. Клейном: Л. С. КлЕйн, Спор о варягах: история противостояния и аргументы сторон (Санкт-Петербург: Евразия, 2009); ср. схожие подходы в изданной посмертно монографии советского диссидента, готовившейся в годы обучения в Московском гос. университете: А. А. АмАльрик, Норманны и Киевская Русь, науч. публикация, предисловие и комментарии О. Л. Губарева (Москва: НЛО, 2018). Актуальным остается и анализ становления академической историографии «варяжской руси»: С. В. Соколов, Концепции проис- 
общество, по крайней мере, ко второй половине IX в., созрело для создания государства. Наивным и архаичным способом демонстрации этой зрелости остается историографический стереотип, восходящий к славянофильским конструкциям XIX в. и средневековым этимологическим опусам, выводящим варягов и начальную русь из славянского мира. Отсутствие фактических данных, обнаруживающих такой ход этногенеза и политогенеза, заставляет обращаться к трудам антинорманистов XIX в. - тиражировать сочинения А.С. Гедеонова ${ }^{13}$ и др., ссылаться на авторитет М.В. Ломоносова, как историка, чьи конструкции были отвергнуты уже классической наукой XIX в. Е.А. Мельникова назвала эту реанимированную (под руководством возглавлявшего тогда институт Российской истории А.Н. Сахарова) историографическую тенденцию «ренессансом средневековья»14.

Перспективными представляются поиски социальных трансформаций внутри восточнославянского общества, точнее, тех образований, которые в советской период принято было называть союзами племен, хотя в ПВЛ они именуются «языками», народами (этносами в византийской традиции, ориентированной на Библию). Эти «языки» явно относятся к таксономически разным общностям от полян, чья территория ограничивается киевским Поднепровьем, до кривичей, расселенных по окраинам всего восточнославянского мира в верховьях Днепра, Западной Двины и Волги. Обычно их принято именовать просто «племенами», в соответствии со значением, установившемся в этнографии XIX в.: племя - эндогамное объединение, недаром в ПВЛ эти языки различаются «отеческими обычаями», в том числе брачными ${ }^{15}$. Начальное летописание противопо-

хождения варяжской руси в российской историографии XVIII-XIX вв. в контексте европейских идей раннего нового времени (Екатеринбург: Банк культурной информации, 2015). Ср. обзор проблемы в книге: В. Я. ПетРухин, Русь христианская и языческая: Историко-археологические очерки (Санкт-Петербург: Изд-во Олега Абышко, 2019), 454-472.

13 Первое изд. - С. А. ГЕдЕонов, Варяги и Русь. (Москва: Русская панорама, 2004), переиздана в 2018. Ср. обращение к донаучной традиции - работам Ю.И. Венелина, романтика, боровшегося со «скандинавоманией» в 1830-е гг.: В. В. Фомин (сост.), Скандинавомания и ее небылицы о русской истории (Москва: Русская панорама, 2015).

14 Е. А. МЕльниковА, „Ренессанс Средневековья? Размышления о мифотворчестве в современной исторической науке", Родина, по. 3 (2009): 56-58 и Родина, no. 5 (2009): 55-57. Ср. недавний аналитический обзор: Д. Н. ВеРхотуров, Три века спора о варягах. Летопись и варяги (Москва: «Вече», 2020).

15 ПВЛ, 10. 
ставляет эти «языки» «новому народу», крещеной в конце X в. Руси. Основы быта этих «языков» сводились к архаическим родоплеменным традициям ${ }^{16}$. Известие ПВЛ о «княжениях» (у полян, древлян, дреговичей, словен и полочан) связано в летописном контексте с книжной конструкцией, утверждающей княжеский статус легендарного Кия, и не содержит информации о социальной структуре «княжений»17; в советской историографии (В.В. Мавродин и др.) они идентифицировались с племенными союзами, с обращением (начиная с 1980-х гг.) к понятиям западной социальной антропологии распространенным стало обозначение предгосударственных образований термином вождество (chiefdom), полития и т.п. ${ }^{18}$.

Так или иначе, за информацией о социальной структуре славянского общества в предгосударственный период стали обращаться к внешним источникам. Опыт их формализованного («контент»-) анализа был предложен Е.А. Шинаковым, отмечающим (вслед за востоковедами), что славяне (ас-сакалиба) и «русы» (ар-рус) у восточных авторов относятся к разным общностям ${ }^{19}$. Автор осознает сложности этого подхода, особенно в отношении терминологии источников, далеких от формализованных требований «научности». Трудно интерпретировать и лексику восточных источников, относящуюся к понятиям «государство» (мамлакат) и «царь» (малик).

Особое место в опытах реконструкции догосударственных образований у славян занимают «славинии» несмотря на то, что этот «гапакс» был употреблен лишь Константином Багрянородным, который перенес этот термин на Восточную Европу: под «славиниями» греки понимали разные территориальные объединения балканских славян; Г.Г. Литаврин подчеркивал территориальное значение термина, а в качестве восточноевропейского примера славинии приводил «княжение» летописных древлян, восставших против Руси в сер. X в. ${ }^{20}$ A. А. Горский отождествляет славинии

16 В. Я. ПетРухин, Древняя Русь. Народ. Князья. Религия, Из истории русской культуры. Т. 1 (Москва: Языки русской культуры, 2000), 314-315.

17 ПВЛ, 10.

18 См.: обзор историографии - Е. А. Шинаков, Образование Древнерусского государства. Сравнительно-исторический аспект (Москва: Вост. лит. 2009), 24-65.

19 Е. А. ШинАков, Образование Древнерусского государства, 69 и сл.

20 Ср. комментарий Г. Г. ЛитАВРинА (Текст, перевод и вступительная статья), КонстАнтин БАГРяноРОдныЙ. Об управлении империей, 317-318. 
с летописными «племенами» (языками) эпохи расселения славян, отмечая, что у Константина Багрянородного население славиний пактиоты (данники) росов, но сложение славиний относит к догосударственной эпохе расселения славян во второй половине 1-го тыс. н.э. ${ }^{21}$ Е. А. Шинаков отождествляет славинии Константина Багрянородного с летописными «княжениями», и хотя приведенный выше список этих княжений (племен/языков) никак не совпадает со списком пактиотов у Константина, исследователи ссылаются на возможности его расширения за счет расхожего выражения - «Славяне же их пактиоты, а именно: кривитеины, лендзанины и прочие Славинии». ${ }^{22}$

Е. А. Шинаков продолжает сопоставление предложенного им тождества (славинии=княжения) с принятыми им конструктами: славинии и княжения равны у него вождествам. Предгосударственные славинии-княжения-вождества доживают свой век в виде низшего уровня примитивного «двухуровневого государства», переходного к собственно раннегосударственной структуре, формирующейся уже в рамках христианской государственности при Владимире Святославиче. Этой историографической конструкции близки представления М. Б. Свердлова о «потестарном государстве» первой половины X в., в котором сохранялась автономия «племенных княжений» ${ }^{23}$. Поиски характерных черт этих предгосударственных образований, которые возводятся к эпохе расселения славян, осложняет не только отсутствие источников, определяющих эти черты - мало информативными оказываются и археологические источники. Для характеристики вождеств-княжений нужны, по меньшей мере, свидетельства наличия вождей (князей). Эти свидетельства считались очевидными в «автохтонистской» историографии середины XX в.: русское государство должно было формироваться в Среднем Поднепровье, вокруг Киева - летописной «матери городов русских», и богатейшие комплексы типа Перещепины с наборами парадной золотой и серебряной полуды, парадного оружия и т.п. приписывались славянским вождям, обогатившимся во время походов славянских племен (на юге Восточной Европы - антов)

21 А. А. Горский, Русь: от славянского Расселения до Московского царства (Москва: ЯСК, 2004), 20-35.

22 См.: КОНСТАНТИН БАГРЯНОРОДНЫЙ. Об управленИи империей, 45, 51.

23 М. Б. СвеРДЛОВ, ДомонгольСКая РУСь, 163-181. 
эпохи расселения славян (VI-VIII вв.). Несравненно более скромные «клады» - комплексы украшений юга Восточной Европы еще А. А. Спицын в 1928 г. назвал древностями антов, Б. А. Рыбаков в 1953 г. древностями русов, дав им характеристику «дружинной культуры», несмотря на отсутствие там предметов вооружения. Традицию продолжили А.Т. Смиленко, В. В. Седов (выводивший «русов» в составе этой южной группировки славян с Дуная) и др. ${ }^{24}$

В полемике, которая развернулась вокруг комплексов, носивших дружинный (комплекс у Вознесенки содержал многочисленные предметы вооружения) и «вождеский» характер, возобладала взвешенная их атрибуция кочевой (болгаро-хазарской) элите ${ }^{25}$. «Древности антов» также испытывали воздействие культуры Византии, кочевников и германцев (готов), на первом этапе (VI-VII вв.) - авар, на втором - хазар ${ }^{26}$; синтез разноэтничных импульсов в культуре славян демонстрирует разрушение у них родоплеменной замкнутости. Можно предполагать, что эти клады отражают формирование

24 В. В. СЕдов, Славяне: историко-археологическое исследование (Москва: Яск, 2002), 203-294. Второе изд. книги вышло в 2019 г. Переиздаются и книги Б. А. Рыбакова (в частности, монография «Киевская Русь и русские княжества XII-XIII вв.» переиздана в 2016; особой популярностью, в том числе у «неоязычников», пользуются многостраничные монографии по язычеству древних славян и древней Руси. Рыбаков был далек в своих реконструкциях от использования грубых фальсификаций в духе «Влесовой книги» и т.п., на которых основываются сочинения неоязычников. См. критику историографического стереотипа «двоеверия» В Кн.: ВАЛЕРИ КИВельсон, Магия отчаяния: моральная экономика колдовства в России XVII века, пер. с англ. В. Петров (СПб.: Academic Studies Press/ БиблиоРоссика, 2020), 70 и сл.

25 А. К. АмБРОз, «О Вознесенском комплексе VIII В. на Днепре - вопрос интерпретации», в А. К. АмБРоз, И. Ф. ЭРдЕли (ред.) Древности эпохи великого переселения народов V-VIII вв.: Советско-венгерский сборник, (Москва: Наука, 1982), 204-221. Ср. из недавних работ: Б. Тотев, О. ПЕЛЕвинА, «Сокровище из Малой Перещепины и элитарная культура болгар Нижнего Дуная», в Форум «Идель - Алтай». Серия «Археология евразийских степей». Вып. 13 (Казань: Институт истории АН РТ, 2010), 174-179.

26 О. А. ЩЕгловА, «Волны распространения вещей из Подунавья: отражение славянской миграции или культурных инфильтраций?», в Сложение русской государственности в контексте раннесредневековой истории Старого света. Материалы международной конференции. Труды Гэ. Вып. XLVIII. (Санкт-Петербург: Издательство Государственного Эрмитажа, 2009), 39-65. Ср. А. М. ОБломский, «Структура населения лесостепного Поднепровья в VII в. н. э.», в ДГ 2010 год: Предпосылки и пути образования Древнерусского государства, ред. Е. А. МЕльниковА (Москва: Ун-т Дмитрия Пожарского, 2012), 10-33; М. М. КАЗАнский, «О расселении славян в лесной зоне Восточной Европы: предметы раннесредневекового убора дунайского происхождения (VI-IX вв.)», AB, вып.28 (2020): 258-271. Ср. из обобщающих работ: М. Б. Щукин, Готский путь (Санкт-Петербург: Филологический факультет СПбГУ, 2005). DOI: 10.31600/1817-6976-2020-28-258-271 
«престижной экономики», особого отношения к «богатству», значимость которого для «варварских обществ» Европы в процессе «генезиса феодализма» показал А. Я. Гуревич. Импульсы, идущие с юга и Балкан достигали восточноевропейского Севера, в том числе Ладоги, возникновение которой относится к VIII в. Уже в эпоху становления славянской археологии очевидным было отличие славянской культуры от традиций соседей: погребальный обряд был «бедным», лишенным престижных вещей и вооружения (что подчеркивал еще классик славянской археологии Л. Нидерле). ${ }^{27}$

Обнаружение ожидаемых тенденций с опорой на археологию затруднительно: упомянутое тождество «вождество - княжение - славиния» рассыпается при обращении к контексту источников: славиниями Константин Багрянородный именует объединения неких лендзанинов и кривитеинов - кривичей. Славинии кривичей уделяется особое внимание, хотя их широкое расселение и локальные различия в культуре приписываемых им (со времен А. А. Спицына) длинных курганов затрудняют интерпретацию кривичей как общности, как некоего предгосударственного образования ${ }^{28}$.

Единственный летописный «казус», который может характеризовать «славинии» как «княжение» - древляне: во время восстания против русского князя Игоря (в ПВЛ под 945 г.), древляне казнили его и противопоставили ему своего главного (?) князя Мала и других князей, что «распасли суть Деревьску землю». Все это характеризует восточнославянские вождества, которые возглавляет «федеральный князь», ему подчинены «племенные» князья и «старейшины градов» и т. п. ${ }^{29}$ Сам термин земля означает в летописании территориальное (предгосударственное?) образование в отноше-

27 ЛЮБор НИДЕРЛЕ, СЛавянсКИе Әревности, Пер. С ЧешсК. Т. КОВАЛЕВОЙ, М. ХАЗАНовА (Москва: изд-во иностранной литературы, 1956) 208; ср. Н. И. ПлАтоновА, «Древнерусская культура и древнерусская элита: проблемы и перспективы исследований», в Н. И. Платонова (ред.) Élite ou Égalité... Северная Русь и культурные трансформации в Eвропе VII-XII вв., (Санкт-Петербург: Издательский дом «Бранко», 2017), 9-29. Автору приходилось настаивать на этой специфике погребального культа славян и, соответственно, на сомнительности прямолинейных социологических конструкций, выводящих из наличия «богатых» погребения свидетельства формирования социальных классов и т. п.: В. Я. Петрухин, Русь в IX-X вв.: от призвания варягов до выбора веры. (Изд. 3-е, испр. и доп., вышло в 2017), 297-299. Ср. А. А. Горский, Русь от славянского расселения... 109-111.

28 Ср. А. А. Горский, РУсь от славянского расселения... 27 и сл.

29 Ср. М. Б. СвеРдЛов, Домонгольская РУсь, 163 и сл.; Е. А. ШинАКов, Образование Древнерусского государства, 158-160. 
нии архаических этнических общностей (Польская земля полян и т. п.)..$^{30}$

Сюжет древлянского восстания имеет ближайшую параллель в знаменитом летописном рассказе о начале Русской земли - призвании варяжских князей (ПВЛ под 859/962 г.). После рассказа о варяжской дани «на чюди, на словьнех, на мери и на всьхъ кривичьхъ» говорится об изгнании варягов за море, усобицах («въста родъ на родъ») и решении - «поищемъ собь князя, иже бы володьлъ нами». От призванных варягов «прозвася Руская земля». Естественно, обнаруживать в этом рассказе прямые свидетельства формирования государства (земли) из распадающегося родоплеменного строя принято было разве что во времена С. М. Соловьева; В. Т. Пашуто предполагал существование принимающей консолидированное решение межплеменной конфедерации, немыслимой при «родовом строе» ${ }^{31}$. Немыслимо и соотнесение этой конфедерации со «славиниями» (чудь и меря - не славяне). Территориальная характеристика конфедерации - «земля наша велика и обильна» - скорее ассоциируется с библейским представлением об обетованной земле, чем с некими этнополитическими границами.

Так или иначе, затронутые проблемы не могут решаться без выяснения отношений славян (славиний) и других «языков» с летописной русью («росами» Константина Багрянородного), в концепции «двухуровневого государства» переходного периода у Е.А.Шинакова, «потестарного государства» у М. Б. Свердлова, за которым следовало «становление и консолидация раннего государства Русь» ${ }^{32}$. «Двухуровневое государство», соотнесенное с более распространенным термином «варварское государство», воплощает Росия Константина Багрянородного. И хотя территориальное

30 А. А. Горский, Русское средневековое общество: историко-терминологический справочник (Санкт-Петербург: Изд-во Олега Абышко, 2019), 157-158.

31 Модификация текста ПВЛ в Новгородской первой летописи (НПЛ), где призывающие «языки» - словене, кривичи, меря (и чудь) «свою волость имели», вызывает ассоциации с известными в средневековый период и позднее, вслед за И. Я. Фрояновым, «территориально-политическими единицами» (А. А. Горский, Русское средневековое общество, 67). Однако этим ассоциациям противоречит последующая летописная фраза - «кождо своимъ родомъ владяще» (НПЛ. С. 106). «Надродовым» владением - властью в обеих редакциях легенды о призвании наделяются призванные «володеть» князья.

32 Ср. М. Б. СвеРдЛОв, Домонгольская Русь. С. 182-307; Е. А. ШинАКов, Образование Древнерусского государства, 173-299. 
пространство этой Росии в отношении со «славиниями» и даже печенегами не вполне ясно, сама концепция «двухуровневого государства» соответствует сложившейся на широком евразийском материале историографической тенденции - выделении «двойных элит», включающих элиту подчиненных этносов, и даже выделение «этносов-элит» ${ }^{33}$. Последний концепт очевидно напоминает летописные данные о роли варягов (руси-дружины) и хазар в начальной истории славян, легендах о хазарской дани и призвании варягов.

Построение альтернативной летописи исторической ретроспективы связано с известием Бертинских анналов о народе «рос», помещенном под 839 г., и, стало быть, «опровергающим» летописное известие о появлении Руси с призванными варяжскими князями под 862 г. Действительно, с византийским посольством император Феофил посылает в Ингельхайм к Людовику Благочестивому неких людей, именующих свой народ «рос», а своего правителя «хаканом». На поверку эти люди оказались свеонами (шведами) и были задержаны Людовиком, врагом викингов ${ }^{34}$. Интерпретация этих известий укладывалась в традиционную схему «южного» (среднеднепровского) происхождения руси и русской государственности - некоего «Росского каганата» (у В.В. Седова и др.); модифицированная точка зрения, учитывающая скандинавское происхождения людей «рос», помещает «Русский каганат» на севере Восточной Европы (его центром считается не Киев, а Ладога или новгородское Городище), соответственно можно было предлагать «перестройку» летописной истории и т.п. ${ }^{35}$

При этом игнорировалась и отмеченная еще В.О. Ключевским параллель посольству в Ингельхайм: тогда же (838 г.?), по сообщению Константина Багрянородного, хазарский хакан отправил посольство с просьбой прислать инженеров для строительства крепости Саркел на Донуз ${ }^{36}$ «Люди рос» оказывались частью посольства хазарского, а не «росского» хакана. Намечается возвращение к этому более экономному пониманию источников (не требующего «аль-

33 Н. И. ПЛАТОНОВА, Указ. Соч., 19-20.

34 См: комментированный перевод: ДРЗИ: T. IV. Западноевропейские источники, сост., пер. и КОМм. А. В. НАЗАРЕНКО, 17-21.

35 КОНСТАНТИН ЦУКЕРМАН, «Перестройка древнейшей русской истории, у истоков русской государственности», в У истоков русской государственности, ред. Е. Н. НосоВА, А. Е. МУСИнА (Санкт-Петербург: Дмитрий Буланин, 2007), 334-351.

36 КОНСТАНТИН БАГРЯНОРОДНЫЙ, УКаз. Соч., 52-53, 334, 401. 
тернативной истории» Русского каганата): начальная Русь включилась в геополитическую систему противостояния раннесредневековых «империй» - «кочевой империи» хазар, Арабского халифата и Византии; Русь под эгидой хазарского кагана претендовала на дружественные отношения с Византией (Д. Оболенский навал эти отношения империи с «варварами» Византийским содружеством) $)^{37}$.

С критикой сложившихся в советской историографии стереотипов генезиса государства и феодализма в Киевской Руси выступал с 1970-х гг. И.Я. Фроянов. Он настаивал на доклассовом характере складывающихся в домонгольской Руси общественных отношений, которые сводил к формированию на основе «этнополитических» племенных союзов территориально-политических структур - волостей, объединяемых вокруг главного вечевого города с подчиненными ему городскими центрами. Эти структуры он именовал «городами-государствами», сопоставляя их с античными полисами. Поскольку процесс формирования таких структур (в том числе городской сети) ${ }^{38}$, в отличие от полисов, не прослеживается на основе источников по истории и археологии Восточной Европы, эта историографическая тенденция представляется умозрительной (если не «химерической» в терминологии одного из соавторов Фроянова). ${ }^{39}$

37 Ср. А. П. Толочко, Очерки начальной руси (Киев; Санкт-Петербург: Лаурус, 2015), 111 и сл. См также: В. Я. Петрухин, «Хазарское начало русской истории», в А. М. Бойцов, О. В. Воскоьойников (ред.). Polystoria. Зодчие, конунги, понтифики в средневековой Европе, Изд. 2-е (Москва: Высшая школа экономики, 2021), 43-86.

38 Во многом умозрительной остается и попытка Б. А. Тимощука выстроить схему развития «градообразовательных процессов» от общинных поселений к «феодальным городам» (при особых отношениях с «княжескими крепостями» - Б. А. Тимощук, Восточные славяне: от общины к городам (Москва: изд-во Моск. ун-та, 1995).

39 Непредвзятая краткая характеристика обвинений Фроянова в отходе от формационного подхода в советской официозной историографии дана в популярной книге: В. Б. КоьРин, Кому ты опасен, историк? (Москва: Московский рабочий,1992) 180 и сл. Переиздается монография И. Я. ФРояновА, «Древняя Русь: Опыт исследования истории социальной и политической борьбы» (Санкт-Петербург; Москва: «Златоуст»,1995; Москва: Русский издательский центр, 2021). Один из ближайших сотрудников и соавторов И. Я. Фроянова А. Ю. Дворниченко издал объемистую историографическую монографию, ориентированную на концепцию Фроянова: А. Ю. Дворниченко, Зеркала и химеры. О возникновении древнерусского государства (Санкт-Петербург; Москва: Евразия, 2014). См. об издержках этой ориентации: В. В. ПузАнов, „Химеры в кривом зеркале историографии”, Вестник СПбГУ. История 62, no. 2 (2017): 418-432. DOI: 10.21638/11701/spbu02.2017.216; впрочем, некоторые позиции самого В. В. Пузанова близки установкам Фроянова: см. В. В. ПузАнов, Om праславян к Руси: становление Древнерусского государства (факторы и образы 
Так или иначе, летописная традиция, в том числе легенда о призвании варяжских князей, оказывается в центре дискуссий о формировании государственности. Популярным в историографии остается подход В. О. Ключевского - «Сказание о призвании князей - схематическая притча о происхождении государства» ${ }^{40}$. Проблему участия норманнов в создании государства историк считал второстепенной, по той причине, что основывал свои представления об этом процессе на находках монетного серебра VIII в. в Восточной Европе: стало быть, думал Ключевский, задолго до варягов здесь существовала товаро-денежная экономика с торговыми городами и т.п. ${ }^{41}$ (эти идеи «буржуазного» историка были поддержаны советской историографией, ищущей автохтонных экономических основ государственности). По данным нумизматики, обращение монеты началось не ранее рубежа VIII и IX вв.: этот процесс охватывал не только речные коммуникации Восточной Европы, но и Балтики (летописного «Варяжского моря»)42. Сокрытие кладов было связано с опасностями транзита, а не с формированием «торговых городов».

Особое значение для понимания исторической ситуации в ее соотношении с летописной традицией имеют данные археологии: очевидные соответствия материалов раскопок и летописных свидетельств, в том числе широкое распространение скандинавских древностей, охватывающее территорию Восточной Европы, в том числе южной Руси (включая Галицкую землю). 43 Незавершенность работ на большинстве памятников, относящихся к начальному

политогенеза) (Санкт-Петербург: Изд-во Олега Абышко, 2017). См.: также о концепции Фроянова в контексте развития советской историографии: М. Б. СвеРдлов, Домонгольская Русь... 26-27. «Химерным государством» Л. Н. Гумилев именовал принявшую иудаизм Хазарию: даже варяжских князей с их устремлением к неограниченному получению дани он считал агентами еврейской торговой верхушки; см. оценку сочинений «последнего евразийца» в книгах: В. А. ШниреЛьмАн, Хазарский миф: Идеология политического радикализма в России и ее истоки (Москва; Иерусалим: Мосты культуры/Гешарим, 2010); Л. А. Мосионжник, Технология исторического мифа (Санкт-Петербург: Нестор-История, 2012).

40 В. О. Ключевский, Указ соч., 155.

41 Там же, 140 и сл.

42 См. переиздание классической работы В. Л. Янина 1955 г.: В. Л. Янин, Денежно-весовые системы домонгольской Руси и очерки истории денежной системы средневекового Новгорода (Москва: ЯСК, 2009).

43 См. специальный выпуск каталога: Ф. АндРощук, В. Зоценко, Скандинавские древности южной Руси (Paris: Інститут археології НАН України, 2012). 
периоду развития Руси (IX-X вв.), не позволяет предлагать окончательные выводы о соответствии летописных данных археологическим. Очевидно, что большая часть упомянутых в Начальной летописи (ПВЛ) городов формировались в этот период и их материалы содержали скандинавские древности - систематический обзор материалов был подготовлен Институтом археологии РАН в упомянутой коллективной монографии «Русь в IX-X вB. Археологическая панорама». Издание было приурочено к юбилею российской государственности, по традиции привязанному к летописной дате призвания варягов (862 г.); многочисленные конференции с продолжающейся публикационной активностью были ориентированы на этот юбилей ${ }^{4}$.

Естественно, особое место в историографии занимает проблема «столиц» начальной Руси, городов, где сели призванные князья. Дискутируется соотношение Новгорода и Ладоги, ибо в Ладоге, согласно ипатьевской редакции ПВЛ, обосновался Рюрик, затем перебравшийся в Новгород. В Ладоге ранние городские напластования датируются сер. VIII в., в Новгороде материалы IX в. сосредоточены на Городище - традиционной резиденции новгородских князей. Соответственно, исследователи Ладоги воспринимали ее как «первую столицу Руси»45. Возглавлявший новгородскую археологическую экспедицию В. Л. Янин видел в Ладоге временную стоянку призванного Рюрика, с которой он перебрался в Новгород/на Городище. ${ }^{46}$ В те же годы проблемы начальной русской истории обсуждались на заседаниях Отделения исторических и филологических наук $\mathrm{PAH}^{47}$,

44 См. публикацию материалов конференции: Сложение русской государственности ... В Институте всеобщей истории РАН - А. О. ЧуБАРьян (пред.), Древняя Русь и средневековая Европа: возникновение государств, Материалы конференции (Москва: Ин-т всеобщей истории РАН, 2012); статьи изданы также в ежегоднике ДГ 2014г.; см. также: Т. Н. ДЖАКсон (ред.), Древняя Русь и средневековая Европа: возникновение государств (Москва: Ин-т всеобщей истории РАН, 2016); издана была энциклопедия: Е. А. МЕЛьниковА, В.Я. Петрухин (ред.), Древняя Русь в средневековом мире. Энциклопедия (Москва: Ладомир, 2014). Выставка в Гос. Историческом музее: Д. В. ЖУРАВЛЕВ, В. В. МурАшевА (сост.) Меч и златник: к 1150-летию зарождения Древнерусского государства (Москва: ГИМ, 2012). В 2012 г. вышло первое издание книги: В. Я. ПЕтРухин, Русь 8 IX-Х вв.: от призвания варягов до выбора веры. (Изд. 3-е, испр. и доп., вышло в 2017).

45 А. Н. КИРПичников, В. Д. САРАБьянов, Старая Ладога - первая столица Руси (Санкт-Петербург: Славия, 2013), 143-169.

46 В. Л. Янин, «О начале Новгорода», У истоков русской государственности, 205-212.

47 Ср. Н. А. МАКАРОВ, Е. Н. Носов, В. Л. Янин, «Начало Руси глазами современной археологии», в Труды отделения историко-филологических наук РАН (Москва: «Наука», 
подчеркивалась значимость славянской земледельческой колонизации для становления государственности (Н.А. Макаров).

Проблемы становления «протогородской» сети на Руси обсуждались на парижской конференции в октябре 1997 г. (материалы изданы в 2000):48 интенсивная полемика продолжается по всем проблемам процессов урбанизации, включая хронологические соотношение урбанистических центров - Новгород/ Городище, Смоленск/ Гнёздово и т.п. Каждый сезон раскопок привносит в полемику новые аспекты; особенно это касается раскопок в Гнёздове, для X в. - крупнейшем по размерам торгово-ремесленном поселении на пути «из варяг в греки». Богатство материала, в том числе кладов и импортов, позволяет его исследователям предполагать самостоятельную значимость Смоленской земли на основной речной магистрали Руси ${ }^{49}$, вопреки данным Константина Багрянородного, свидетельствовавшего в сер. Х в., что Смоленск/Милиниски был данником - пактиотом киевских росов. Со времен А. А. Спицына продолжается дискуссия об отношении Гнёздова к соседнему Смоленску, в котором изучены городские напластования лишь с сер. XI в., а ранние слои изучены фрагментарно ${ }^{50}$. Методы естественных наук позволяют удревнить напластования приднепровской части Гнёздова до последней четверти VIII в..$^{51}$ Это открытие интересно с точки зрения урбанизации в раннесредневековой Восточной Европе, так как датируемые сер. VIII в. напластования Ладоги выглядели изолированно, и Ладога включалась в сеть балтийских, а не континентальных «протогородов». Еще более сложной проблемой остается отсутствие погребальных комплексов IX в. в ладожском некро-

2014), 17-36; В. Я. Петрухин Призвание варягов: традиция и исторические реалии, там же, 289-299.

48 M. KAZANSKI, A. NERCESSIAN, C. ZUCKERMAN (eds.), Les centres proto-urbains Russes entre Scandinavie, Byzance et Orient (Paris: éditions P. Lerthielleux, 2000)

49 Т. А. ПУшкИНА, В. В. МУРАшЕВА, Н. В. ЕНИоСОВА, «Гнёздовский археологический комплекс», в Н. А. МАКАРОВ (ред.). Русь в IX-Х вв. Археологическая панорама, 242-273.

50 См.: В. Я. Петрухин, «К истории давней дискуссии: Смоленск и Гнёздово», в С. Ю. КАинов (ред.). Гнёздовский археологический комплекс: Материалы и исследования. Вып.1, Труды ГИМ, Вып. 210., (Москва: ГИм, 2018), 462-473.

51 В. В. МУРАШЕВА, А. В. ПАНИН, А. О. ШЕВЦОВ, Н. Н. МАЛЫШЕВА, Э. П. ЗАЗОВСКАЯ, Н. Е. ЗАРЕЦКАЯ, «Время возникновения поселения Гнёздовского археологического комплекса по данным радиоуглеродного датирования», Российская археология no. 4 (2020): 70-86. DOI: 10.31857/S086960630012627-8 


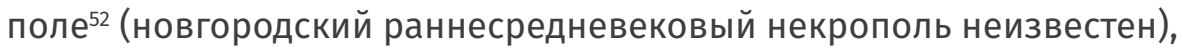
в Гнёздове и в Киеве.

Отсутствие на Руси погребальных комплексов времен Рюрика и Вещего Олега можно гипотетически объяснить возвращением их дружин «за море»: в единственном источнике (явно вторичном по отношению к ПВЛ, подробно рассказывающей легенду об Олеге) в Новгородской первой летописи (НПЛ) говорится, что после победоносного похода на Царьград князь отправился за море, но погиб в Ладоге ${ }^{53}$. Известия, относимые летописью к IX B. (включая дату призвания варягов - 862 г.) носят легендарный характер, датировки условны - реальные даты появляются в связи с открытием договоров руси с греками, в первую очередь - договора Вещего Олега 911 г., что побуждает исследователей «перестраивать» начальную русскую историю54, осторожно начинать исследование «реалий» начальной истории с X в. и т.п. ${ }^{55}$ Наработки предшествующей историографии считаются с этой точки зрения заведомо нерелевантными.

К таким наработкам историографии относится и интерпретация исторического содержания легенды о призвании варягов. Бросающаяся в глаза нелепость летописной конструкции, согласно которой платившие дань варягами «языки» восстали и изгнали их за море, а затем обратились к ним же с призванием на княжение, интерпретировалась с опорой на ПВЛ - обратились не ко всем варягам, а к руси. Ключевский подчеркивал, что это была обычная практика отношений с норманнами - одну группу нанимали для охраны от набегов прочих. В.Т. Пашуто, опираясь на ипатьевскую редакцию ПВЛ, наставил, что князья были приглашены править «по ряду, по

52 «Романтические» взгляды на Ладогу, как первую столицу Руси, приводили к поискам там могилы Рюрика, которую усматривали в единственной камерной гробнице ладожского некрополя с разнообразным инвентарем: ср. В. А. НАЗАРЕНКО, «Могильник в урочище Плакун», в В. В. СЕдов (ред.). Средневековая Ладога (Ленинград: Наука, 1985), 156-169. Однако дендродата этой гробницы - 880-900 гг.: К. А. МихАйлов, Элитарный погребальный обряд Древней Руси (Санкт-Петербург: Издательский дом «Бранко», 2016), 227.

53 В. Я. ПЕтРУХин, «Вещий Олег и “могила в Ладоге"», В С. В. БЕЛЕцКий (ред.). Земля наша велика и обильна: сб. статей посвященный 90-летию А. Н. Кирпичникова (СанктПетербург: Книжная типография, 2019), 302-331. Одна из волховских сопок названа была «Олеговой могилой» в период празднования 1000-летия Руси в 1862 г.

54 К. ЦУКЕРМАН, ПерестройКа... 334-351.

55 Ср. П. С. СТЕФАНовИч, Бояре...; А. С. ЩАВЕЛЕВ, Хронотоп державы Рюриковичей (911987 годы) (Москва: Аквилон, 2020). 
праву» конфедерацией северных племен - данников варягов. Очевидно, что эта гипотеза соотносится с представлением того же Ключевского о летописной «комбинации», призванной придать легитимный характер правлению призванных князей. Однако, трактат Константина Багрянородного демонстрирует специфику даннических отношений «росов» и славян: росы покупали строевой лес, поставляемый им славянами ${ }^{56}$. Этот обмен услугами характерен для «реципрокальных» даннических отношений в архаическом «трибутарном» государстве ${ }^{57}$ и соответствует летописному представлению о договорных отношениях - ряде с призванными князьями и их дружиной (русью) 58 .

Восприятие летописцем известного ему как имя народа - русь как этнонима, сходного с именами свеев, урманов - норвежцев, англов и т. д. в легенде о призвании князей долго сбивало с толку исследователей происхождения этого имени, ибо за «Варяжским морем» не было такого народа. Впрочем, в эпоху становления исторической науки, когда первый русский академик 3. Г. Байер обнаружил, что тем же именем (Ruotsi) прибалтийские финны называют Швецию и шведов, можно было понять, что русь - это экзоним, которым называли выходцев из-за моря жители Прибалтики. Дальнейшие этимологические исследования прояснили значение этого названия - оно означало «гребцов» ${ }^{59}\left({ }^{*} r o ̄ p(e) R-\right.$ «гребец»), дружину, передвигавшуюся

56 КОНСТАНТИН БАГРЯНОРОДНЫЙ, УКаз. соч., 47.

57 Эта терминология, воспринимаемая ныне российскими историками (наряду с понятиями вождество и т.п.), стала внедряться на закате советской историографии: для составления словаря привлечены были коллеги из дружественной Восточной Германии: см. А. И. ПЕРШИЦ, Д. ТРАЙДЕ (ред.), СоцИаЛьно-эКономИчеСКИе отношения и соционормативная культура: Свод этнографических понятий и терминов (Москва: Наука, 1986).

58 В. Я. Петрухин, «В. Т. Пашуто о древнерусской практике ряда», в ДГ 2019-2020 годы: Дипломатические практики Античности и Средневековья (Москва: Ун-т Дмитрия Пожарского, 2020), 42-50. DOI: 10.32608/1560-1382-2020-41-42-50. Представление о «ряде» с призванными варяжскими князьями с точки зрения исконной новгородской вечевой традиции было развито В. Л. Яниным: В. Л. Янин, Начало Новгорода, 208-209.

59 Ср. В. ТомСЕН, «Начало Русского государства», в Из истории русской культуры, Т. ІІ, СОСТ. А. Ф. ЛИТВИНА, Ф. Б. УСПЕНСКИЙ (МосКва: ЯСК, 2002), 196-197; АДОЛЬФ СТЕНДЕР-ПЕТЕРСЕН, Варангика; историко-филологические исследования, (Москва: Варфоломеев, 2021), 18, 53 и сл. См.: переиздаваемый классический словарь - М. ФАСМЕР, Этимологчческий словарь русского языка, пер. и дополнения О. Н. ТРУБАЧЕВА. В 4 т. Т. ІІІ (Москва: Прогресс, 1986), 522-523. 


\section{В. Я. ПЕтрухин}

на гребных судах ${ }^{60}$. Это объясняет «двойственность» значения имени «Рос», относящегося к свеонам, в упомянутом известии Бертинских анналов. Существенно, что прибалтийско-финское название Швеции относится к естественному языку, не имеет книжного характера, который положен в основу постоянно умножающихся кабинетных этимологий, возводящих имя начальной руси к балтийско-славянским или альпийским ругиям, к имени народа-монстра ерос у Псевдо-Захарии $(\mathrm{VI} \text { в. })^{61}$ и еще более древним индоариям, гидронимам типа Рось, Руса, лексемам типа русло ${ }^{62}$, Пруссия/Поруссия ${ }^{63}$ и т.д. и т.п.

Между тем, прибалтийско-финское имя руси определенно указывает на исторический контекст летописной легенды о призвании, ибо во всех летописных редакциях легенды чудь участвует в призвании князей. Не менее существенно то обстоятельство, что первоначальное значение имени русь не связано было с этнической номенклатурой ${ }^{64}:$ имя было дружинным - относилось к тем группам скандинавов,

60 Е. А. МЕЛьниковА, В. Я. ПЕтРухин, «Название "Русь" в этнокультурной истории Древнерусского государства», ВИ по. 8 (1989): 24-38. Ср. археологические данные о руси-гребцах: В. В. МурашевА, С. Ю. КАИнов, ВикингИ. Путь на Восток (Москва: ГИМ, 2020), 40-55.

61 К. А. МАксимович, Происхождение этнонима Русь в свете исторической лингвистики и древнейших письменных источников, KANIEKION. Юбилейный сборник в честь 60-летия профессора Игоря Сергеевича Чичурова (Москва: Православный Свято-Тихоновский гуманитарный университет, 2006), 14-56. См. критику этой и других конструкций - Кулешов В. С. К оценке достоверности этимологий слова Русь, в Сложение русской государственности, 441-459.

62 Ср. Г. ЛОВМЯНЬСКИЙ, «РУссы и рУги», ВИ По. 9 (1971): 43-52; А. В. НАЗАРЕНКО, «Об ИМЕНИ «русь» В немецких источниках IX-XI вв.», Вопросы языкознания no. 5 (1980): 46-56; А. А. ГОРСКИй, РУсь... С. 43-44; А. Г. КУзьмин, М. Ю. ЛАчАЕВА, Н.М. РоГоЖИн, Историография истории России до 1917 год (Москва: Владос, 2004), 28-40; См. о «манипулировании фактами» В зависимости от принятой гипотезы у А. Г. Кузьмина: В. Б. КОБРИН, УКаЗ. СОЧ., 214-215.

63 Е. В. КАМЕНЕЦКАЯ, В. Я. ПЕТРУХИН, «Пруссия и РУсь: средневековЫЙ миф и новейшая историография», Славяноведение no. 5 (2008): 77-83. Продолжают бытовать кабинетные этимологии, интерпретирующие скандинавские имена призванных русских князей Рюрика, Синеуса и Трувора («sine hus» и «thru varing» - «со своим домом и верной дружиной»), попытке отождествлять на основании совпадения имен Рюрика Новгородского и Рорика Фрисландского, Олега Вещего и князя Хлгу Кембриджского документа и т.п.

64 Этноним русичи содержит только «Слово о полку Игореве», ср.: Л. В. Милов, «Ruzzi “Баварского географа" и так называемые "русичи"», Отечественная история no. 1 (2000): 94-101. Патронимические суффиксы и языческие генеалогии - уникальная черта поэтики «Слова», отмеченная еще Е. В. Аничковым, см: Е. В. Аничков, Язычество и Древняя Русь (Москва: Академический проект, 2009), 407-421. Через десятилетия после скандального обсуждения (осуждения) книги А.А. Зимина о позднем 
которые использовали в чудской земле гребные суда. Он усваивался, по наблюдению Ключевского, повсюду, где появлялись русские дружинники, став основой для наименования нового народа в христианской Русской земле. Термин «Русская земля» сохранял в древнерусской традиции не только значение страны, но и народа, в том числе войска: эту двойственность значения демонстрирует уже варяжская легенда - в новгородской редакции «от тьх Варягъ, находникъ тьхъ, прозвашася Русь, и от тьх словет Руская земля»65.

Поскольку дружина, способная оперативно передвигаться по речным и другим коммуникациям, была главным гарантом единства формирующегося на этих коммуникациях государства («земли»), ЭТО ГОСУДАРСТВО ИМЕНУЕТСЯ ДРУЖИННЫМ (Е. А. МЕЛЬНИКОВА) ${ }^{66}$ ИЛИ ТРИбутарным, ибо бюджет дружины и княжеского двора основывался на регулярно собираемой дани (полюдье).

Начальная летопись свидетельствует, что уже призванные князья, а по смерти Синеуса и Трувора и мужи (старшие дружинники Рюрика) опирались на сеть подвластных им «летописных» городов. Раскопки демонстрируют присутствие дружины в Ладоге, на Верхнем (Ярославском) Поволжье (Тимерёво и др.), Верхнем (Гнёздово), и Среднем Днепре (Киев), Подесенье (Чернигов, Шестовица), где исследованы дружинные курганы (с наборами вооружения и т. п.), что позволило предложить ассоциацию поселений, не упомянутых в летописи, но связанных с курганами, с древнерусскими погостами. Их исследование продолжается, умножается и число денежно-вещевых кладов, свидетельствующих о перераспределении дани на погостах и в городах: их концентрация известна в Ладоге, Гнёздове, Тимерёве и на новгородском Городище/Новгороде ${ }^{67}$. Предполага-

происхождении «Слова» в 1960-х гг. с позиций официозной советской историографии, книга эта увидела свет: А. А. Зимин, Слово о полку Игореве (Санкт-Петербург, 2006). Новое лингвистическое обоснование древности «Слова» см. в кн.: А. А. ЗАлизняк, Слово о полку Игореве: взгляд лингвиста (Москва: ЯСК, 2008).

65 НПЛ, 106.

66 Е. А. МЕЛьниковА, Древняя Русь, Всемирная история. Т. 2, отв. ред. А. О. ЧуБАРьян (Москва: Наука, 2012), 372-397. См. обзор историографии, посвященной дружине в кн. П. С. СТЕФАнович, Бояре, отроки, дружины... 45-260 и обсуждение самой монографии - Диалог о книге: П. С. Стефанович. Бояре, отроки, дружины: военно-политическая элита Руси в X-XI вв., Российская история, nо 6. (2014): 3-38.

67 См. недавний обзор инструментов перераспределения весового серебра, ориентированных на восточный рынок: М. О. Жуковский, «Средневековые весовые гирьки с подражаниями арабским надписям», Поволжская археология 26, по. 4 (2018): 117-126. DOI: 10.24852/2018.4.26.117.136 


\section{В. Я. ПЕтрухин}

лись и тенденции противостояняе в этой урбанистической сети «погостов» и вечевых («племенных») городов, подчиненных (как Новгород и (моленск) в XI в. княжеской власти: погосты гнёздовского типа превратились в сельские поселения. ${ }^{68}$ В этой формирующейся городской сети, контролируемой дружиной, как уже говорилось, невозможно обнаружить никаких следов «городов-государств».

Давно осознанная сложность в понимании древнерусской социальной «терминологии» связана с тем, что большая часть этих «терминов» (род, племя, волость, земля) относится к лексике естественного языка (на язык книжности воздействовала при этом лексика библейских переводов), как и термин дружина: понимание термина зависит от контекста источника ${ }^{69}$. Существенно наблюдение Т.Л. Вилкул о преимущественном употреблении лексемы дружина в летописи (прежде всего - ПВЛ): характерно при этом упоминание дружины в «вечевом» (социальном) контексте отношений горожан (киевлян, новгородцев и др.) с князем ${ }^{70}$. Уже текст варяжской легенды, свидетельствующей, что призванные князья «пояша по собь всю русь», ${ }^{71}$ демонстрирует, что речь идет о дружине - НПЛ заменяет непонятное для XIII В. словосочетание «вся русь» на слова «пояша со собою дружину многу (и предивну)» $7^{22}$. Когда летописные тексты содержат спецификацию понятия дружина, выделяя старшую и младшую ее части, категории представителей этих частей - мужей и отроков, то становится очевидным, несмотря на архаическую («родоплеменную») лексику, что речь идет о социальном институте.

68 Ср. давнюю гипотезу: В. Я. ПЕтрухин, Т. А. ПушкинА, «К предыстории древнерусского города», История СССР по. 4 (1979): 100-112 и обзор последующей историографии: В. Я. ПЕТРУХин, К истории давней дискуссии: Смоленск и Гнёздово, 461-472; Н. А. КРеНКЕ, И. Н. ЕРШОВ, В. А. РАЕВА, «Смоленск И Гнёздово» В АВ, вып. 28 (2020): 296-303. DOI: $10.31600 / 1817-6976-2020-28-296-303$

69 Ср.: Т. Л. Вилкул, Люди и князь в древнерусских летописях середины XI-XIII в8. (Москва: Квадрига, 2009), 72 и сл.; П. С. СТЕФАнович, Бояре... 185 и сл.

70 Т. Л. Вилкул, Люди и князь... 74 и сл.

71 ПВЛ, 13.

72 НПЛ, 106. Прямо следуя «схеме» Шахматова, ориентированной на реконструкцию Начального свода, П.С. Стефанович считает редакцию НПЛ первичной, списывая «всю русь» на тенденциозную «идею автора ПВЛ о германо-скандинавском (?) происхождении руси». Противоречащее обстоятельство, что той же тенденции следует уже цитированная НПЛ («от тьх Варягъ... словет Руская земля» (НПЛ, 106) во внимание не принимается. Соответственно архаизируются и данные о дружине во Введении к НПЛ, несмотря на то, что само Введение отсылает к событиям 1204 г. - правлению кесарей Александра (Алексея) и Исакия и последующему татаро-монгольскому нашествию (П. С. СТЕФАНОВич, Бояре... 189-194, 325-327). 
Наиболее полно эта спецификация продемонстрирована в летописном рассказе о дружинных пирах Владимира Святославича князь «пакы творяше людем своимъ: по вся недьля устави на дворь в гридьниць пиръ творити и приходити боляром и гридем, и съцьскымъ, и десяцьскым, и нарочитымъ мужем»³. В списке дружинников - «своих людей» Владимира представлены все этнокультурные компоненты, присущие древнерусской дружинной культуре: тюркский (?) термин боляре; гридь - специализированный термин скандинавского происхождения, обозначающий именно боевую дружину, «гвардию» - телохранителей князя ${ }^{74}$; сотские, десятские, нарочитые мужи - славянская терминология, имеющая и книжные параллели ${ }^{75}$. Эти книжные топосы, в том числе сочетание «бояре и старцы (градские)» вызывают традиционные для историографии ассоциации с разделением княжеской (дружинной) и «местной», «племенной» знати. ${ }^{76}$ Те же ассоциации вызывают упоминания «нарочитых мужей», тем более, что в связи с событиями в «племенной» глубинке «восстания волхвов» в Поволжье упоминаются «старая чадь» (1024) и «лучшие жены» (1071 г.), а после крещения Руси Владимир Святославич «нача поимати у нарочитые чади дБти» на «ученье книжное». ${ }^{77}$

П. С. Стефанович предлагает (вслед за чешским историком Ф. Граусом) для обозначения основной вооруженной силы архаического (трибутарного) этапа государственности термин «большая дружина», при том, что терминологического значения за словом «дружина» автор не признает ${ }^{78}:$ аналогом термина (с учетом вели-

73 ПВЛ, 56.

74 П. С. Стефанович (Бояре... 342-343) сближает значение слова гридь с обозначением домовых слуг (огнищан Русской правды); собирательное гридь близко по форме другому скандинавскому заимствованию - русь: архаическое значение гриди с ее «заморским» происхождением сохранила надпись на стене Софии Новгородской, упоминающая «гридьбу в корабле»: ср. Т. В. РождественскАя, Древнерусская эпиграфика X-XV вв. (Санкт-Петербург: СПбГУ, 1991), 56-57.

75 Т. Л. Вилкул, Люди и князь, 89-91 и др.

76 Ср. Е. А. ШинАков, Образование Древнерусского государства, 288; П. С. СТЕФАНович, Бояре... 216 и сл. Термин «большая дружина» ранее предложил Е.А. Шинаков для обозначения объединяющей ранние фракции (старшую и младшую дружины, дружины родоплеменной знати) «великокняжеской дружины», основы раннего «дружинного государства» эпохи Владимира Святославича и Ярослава (Е. А. ШинАков, Образование Древнерусского государства, 286 и сл.).

77 Ср. А. А. Горский, Русское средневековое общество. С.371. ПВЛ. С. 53.

78 Замечу, что летописи говорят обычно о «малой дружине»- см. примеры в кн.: Т. Л. Вилкул, Люди и князь... 76-79. 
чины) может служить разве что упомянутая русь - «дружина многа» в интерпретации НПЛ. Сам термин требует соответствия в некоей «малой дружине» (малых дружинах), которые автор приписывает формирующейся (боярской?) знати. «Большую дружину» из зависимых гридей/отроков содержит правитель - на Руси киевский князь; это относительно многочисленное войско распадается с формированием самостоятельных земель - «политий» во второй половине XII B., распределяется по гарнизонам новых городов. То обстоятельство, что согласно ПВЛ по разным городам садятся уже призванные князья, а сменяют их «мужи» Рюрика, во внимание не принимается, ибо Стефанович ориентируется не на летопись, а на конструкцию Шахматова - т. н. Начальный свод, а «свод» этих данных не содержит.

Общепризнанной проблемой, характерной для социальной лексики раннего средневековья в целом, является ее нетерминологичность, «текучесть» ${ }^{79}$, зависимость от модуляций книжного или естественного языка. Стремление уловить содержание этих «терминов» приводит к их «терминологическому» анализу - составлению словарей ${ }^{80}$ и энциклопедий ${ }^{81}$. Определяющим для понимания того или иного термина оказывается контекст источника, особенно специализированного - правового: для понимания состава дружины таковым давно признана «Древнейшая правда». Неоднократно анализировавшийся текст о вире - «аще будеть русинъ, или гридьнъ, любо купць любо ябетник, любо мечникъ, аще изъгои будеть, любо словенинъ, то 40 гривенъ положити за нь» ${ }^{82}$ - исследовался, как правило, без учета структуры текста, с раздельным анализом терминов $^{83}$. Между тем для древнерусских текстов характерно помещение в начало списка обобщающего термина, каковым здесь является термин русин (ед. число от собирательного русь): ему про-

79 Ср. Т. Л. ВИлкУЛ, Люди и князь. 15 и сл.; П. С. СТЕФАНОВИЧ, Бояре... 235-247. Вместе с тем остается актуальным изучение социальной лексики: ср. в советской историографии - В. Т. ПАшУто, Л. В. ЧЕРЕПнИн (ред.), Древнерусское государство и его международное значение (Москва: Наука, 1965) и компендиум: А. А. Горский, В. А. Кучкин, П. В. ЛУкин, П. С. СТЕФАНович, Древняя Русь: очерки политического и социального строя (Москва: Индрик, 2008).

80 А. А. Горский, Русское средневековое общество: историко-терминологический справочник.

81 Древняя Русь в средневековом мире. Энциклопедия.

82 А. А. Зимин, Правда Русская (Москва: Древлехранилище, 1999), 358.

83 Ср. П. С. СТЕФАНович, Бояре... 341 и сл., 513. 
тивопоставлен заключающий список словенин ${ }^{84}$. Стало быть, к руси относятся здесь гридень, купец, и сборщики податей - ябетник и мечник. К корпорации - «большой дружине» (предпочтительнее здесь говорить о дружине «в широком смысле») ${ }^{85}$ может относиться и изгой - включение в состав дружин разнообразных маргинальных элементов, включая несвободных людей. ${ }^{86}$

Очевиден «обратный» порядок в перечне дружинников князя Всеволода Юрьевича (1177 г.), опиравшегося в борьбе за владимирский стол на Ростов: князь «совокупивъ ростовци и боляре гридьбу и пасынки и всю дружину» ${ }^{87}$. Термин «вся дружина» резюмирует здесь весь перечень, в котором бояре сближаются с гридями; уникальный термин пасынки соответствует в архаической «возрастной» иерархии «детским» ${ }^{88}$. Если гриди и русь относятся к аутентичной терминологии, то не только «старцы» (и «отроки»), но и «бояре/боляре» обнаруживают книжные истоки ${ }^{89}$. Термин бояре/боляре - предмет непрекращающихся дискуссий как этимологических, так и исторических. Ему посвящена большая часть монографии П.С. Стефановича: автор не принимает традиционного в историографии прямого соотнесения бояр с мужами - старшей дружиной, настаивает на «расплывчатом» и не корпоративном характере дружинного феномена, что порождает дискуссию о содержании термина боярин ${ }^{90}$. Дискуссию осложняет неясность самого происхождения слова боярин/болярин - безусловно заимствованного: наиболее очевидны

84 О противопоставлении этих «категорий» в начальном летописании свидетельствует сюжет о наделении руси драгоценными парусами, в отличие от словен в войске Олега (907 г.). Ср. о структуре списка, исследованной Г. С. Лебедевым: Г. С. ЛЕБедев, «Комментарий к статье I Русской правды Краткой редакции», в Генезис и развитие феодализма в России. Вып. 10, ред. И. Я. Фроянова (Ленинград: изд-во ЛГУ, 1987), 78-84, В. Я. ПЕТРУхИн, РУСь в ІХ-Х в8., 288-295.

85 Такое различение представляется релевантным для российской историографии - ср. различение (А. Н. Насонов) летописной «Русской земли» в широком и узком смысле: все восточнославянские земли и домен киевского князя в Среднем Поднепровье.

86 Ср. Л. ДРэгЕР, «Дружина», в Социально-экономические отношения, 53.

87 ПСРЛ. Т. 1, 380.

88 Ср. А. А. Горский, Русское средневековое общество, 243.

89 Ср. Т. Л. Вилкул, Люди и князь... 88 и сл. (вслед за С. В. Завадской).

90 Впрочем, Стефанович допускает что «княжие мужи», вроде Свенельда, позднее (в XI в.?) составляют «боярство» (П. С. СтЕФАнович, Бояре... С. 534). См. критику непоследовательности конструкций цитируемого автора в кн.: А. А. Горский, Русское средневековое общество, 21-29. 
его праболгарские (тюркские) истоки - праболг. «боила», обозначение представителя элиты.

Исследование заимствованной иноэтничной социальной лексики в славянском мире создает особые хронологические проблемы: к праславянскому периоду относится заимствованный из западно-герм. термин князь ${ }^{91}$. К праславянскому («аварскому») может возводиться и заимствование терминов каган и бояр(е/ин) ${ }^{92}$ : но в восточнославянском мире титул каган явно увязывается с Хазарским каганатом и временем проникновения в славянскую Восточную Европу и Хазарию руси в IX в.

Летописные тексты обнаруживают характерную тенденцию стремление легитимировать род Рюрика, как единственный на Руси княжеский род: судя по разным летописным памятникам, эта тенденция победила в домонгольский период. Договоры руси с греками, в первую очередь - договор Олега 911 г. конкретизируют этот род. В преамбуле договора, после перечисления послов «от рода рускаго» (носящих скандинавские имена), говорится, что они посланы «от Олга, великого князя рускаго, и от всьх, иже суть под рукою его, свьтлых и великих князь, и его великих бояръ».93 Традиционная историография усматривала в этом перечне иерархию князей восточноевропейского государства - Русской земли договора; киевскому великому князю подчинялись локальные великие князья и его бояре. В локальных князьях готовы были усматривать князей славянских «племенных союзов» и т. п. П. С. Стефанович предложил другую трактовку этой номенклатуры: скандинавские имена послов не позволяют увязать их со славянской элитой (хотя на служебной роли этих скандинавов у славянской знати постоянно настаивали критики «норманизма»)94. Отвергая «киевоцентризм»

91 О. Н. ТРУБАЧЕв (ред.), Этимологический словарь славянских языков. Вып. 13 (Москва: Наука, 1987), 200-201.

92 О воздействии аварской культуры на праславян говорилось выше. См. препринт безвременно ушедшего специалиста по сравнительному языкознания: Е. ХЕлимский, «Тунгусо-маньчжурский языковой компонент в Аварском каганате и славянская этимология", в Материалы кдокладу на ХІІІ Международном съезде славистов, Любляна, 15-21 августа 2003 (Hamburg: Institut für Finnougristik/Uralistik, 2003).

93 ПВЛ, 18.

94 Действительно, этническая ситуация внутри русского княжеского рода изменилась в 940-е гг.: сын Игоря и Ольги носил славянское имя Святослав, своего посла со скандинавским именем имели Володислав и некая Передслава (имя - известное позднее в княжеском ономастиконе: см. об именах - А. Ф. ЛитвинА, Ф. Б. Успенский, Выбор имени у русских князей в X-XVI вв. (Москва: Индрик, 2006). 
традиционной историографической конструкции (с великим киевским князем), исследователь, однако, не учел, что «киевоцентризм» диктуется не старой историографией «Киевской Руси», а самими источниками - не только «тенденциозной» летописью (включая реконструированный «Начальный свод»), но и Константином Багрянородным, видевшим в Киеве сосредоточение «всех росов», собирающей дань со славян.

Сопоставление данных договоров руси с греками и верифицирующих историческую ситуацию на Руси «извне» сочинений Константина Багрянородного создает немало проблем. Элиту «Росии» Константин именует просто «архонтами»; П. С. Стефанович считает, что греческий термин переводится в договорах адекватно - обозначает в древнерусском тексте не только князей, но и бояр. Более того, вопреки приведенным данным летописи, автор уравнивает статус русских князей и бояр (коли все они архонты) и определяет численность этой элиты трибутарного государства в 25 чел. Далее, отмечая сложности проведения большого полюдья из Киева (днепровский маршрут от Киева до Смоленска реконструирован Б.А. Рыбаковым), он считает нерелевантным сообщение Константина о том, что архонты «со всеми росами» выходят в полюдье из Киева, и распределяет сбор дани между 25 лидерами элиты, обретающихся в неких локальных центрах, независимых или «полунезависимых» от Киева, но все же «признающих верховную власть киевского князя»95. Архонты-князья-бояре, таким образом, практически выводятся «из под руки» такого же архонта - киевского князя, обретают относительную независимость от Киева. Эта конструкция с энтузиазмом была воспринята некоторыми археологами, впечатленными богатством исследуемых ими памятников ${ }^{96}$. Поиск таких волостей не более продуктивен, чем упомянутые поиски восточнославянских городов-государств. Летописные примеры демонстрируют судьбы таких волостей, будь то полянское княжение Аскольда и Дира, древлянское княжение Мала или полоцкое княжение Рогволода: попытка перераспределения дани встречает оперативный отпор

95 П. С. СТЕФАНОВИЧ, Бояре... 361-440, 543.

96 Т. А. ПУшкинА, В. В. МУРАшЕВА, Н. В. ЕНИосовА, Гнёздовский археологический комплекс, в Н. А. Макаров (ред.). Русь в IX-X вв. Археологическая панорама, 242-273.; замечу, что региональный подход определяет структуру и самой «Панорамы» Руси IX-X вв., представленной цитируемым компендиумом. 
из столичных центров (обозначенных и летописью, и Константином Багрянородным) - из Киева или Новгорода.

Не меньше дискуссий (чем «дружинное государство» и степень его единства) вызывает и проблема социального устройства внутри волостей - проблема веча, остро поставленная для главного вечевого города - Новгорода В.Л. Яниным. Как и за словом «дружина», за словом «вече» не признается терминологического содержания: его смысл зависит от контекста источника. Янин выступил против романтического взгляда на новгородское вече как на собрание «всех новгородцев» на обширной вечевой площади - такой площади новгородские раскопки не обнаружили. Власть («вечевая» основа новгородской традиции) сосредоточивалась в руках племенной боярской аристократии - владельцев усадеб, последовательность этих владений археологически прослеживается вплоть до X $\mathrm{B}$. (древнейших напластований Новгорода), эта власть древнее власти князей, призванных «из-за моря» аристократической верхушкой. Поскольку институты веча документально прослеживается лишь в поздний период (при формализации отношений Новгорода с Литвой в XV в.), проблема функционирования веча остается предметом острой дискуссии, включая предполагаемые «родоплеменные» истоки веча и боярства ${ }^{97}$. Проблема приоритета «вечевого» права во многом зависит от результатов раскопок в «вечевом» Новгороде и на «княжеском» Городище: их сосуществование в X в. во многом определило представление В. Л. Янина о летописном «ряде» с призванными князьями 98.

Трудноразрешимой проблемой (при отсутствии актовых источников) остается и проблема феодализации - «оседания» дружинников «по земле», поставленная в советской историографии С.В. Юшковым в 1920-е гг.; ${ }^{99}$ на археологическом материале - топографии дружинных комплексов в Черниговской земле ее наметил Б.А. Рыбаков на рубеже 1940-х - 1950-х гг., автор этого очерка указывал

97 Ср. материалы международного круглого стола: М. М. Кром (ред.). Споры о новгородском вече: междисциплинарный диалог (Санкт-Петербург: Европейский университет, 2012); и фундаментальную монографию - П. В. Лукин, Новгородское вече (Москва: Индрик, 2014). Слово «вече» относится к праславянской лексике, но не имеет строгого терминологического содержания; термин «бояре» не вписывается в контекст родоплеменной архаики.

98 См. В. Я. ПЕтрухин, «В. Л. Янин и призвание варягов», Новгородский Исторический Сборник 19 (29) (2020): 29-37.

99 См. М. Б. СвеРдЛов, Домонгольская РУсь. 17 и сл. 
на распространение этих комплексов X в. в пределах Русской земли (в узком смысле) и на землях, не занятых «племенными» поселениями ${ }^{100}$. Становление феодальных отношений на Руси, учитывая характеристику «фьефов, состоявших только из даней», данную Марксом, продолжает М. Б. Свердлов. ${ }^{101}$

\section{Сокращения}

АВ - Археологические вести. Санкт-Петербург: Ин-т истории материальной культуры РАН.

ВИ - Вопросы истории. Москва.

ГИМ - Государственный исторический музей. Москва.

ДГ - Древнейшие государства на территории СССР: Материалы и исследования (с 1975 по 1993 гг.); Древнейшие государства Восточной Европы: Материалы и исследования (с 1994 г.). Москва.

ДРЗИ - Древняя Русь в свете зарубежных источников. Хрестоматия. Москва. Т. І. Античные источники, сост. А. В. Подосинов., 2009; Т. III. Восточные источники. Хрестоматия, сост. Т. М. Калинина, И. Г. Коновалова, В. Я. Петрухин. 2009; T. IV. Западноевропейские источники, сост., пер. и комм. А. В. Назаренко. 2010.

НПЛ - Новгородская первая летопись старшего и младшего изводов. М., 2000, ПСРЛ. Т. 3 (репринт издания под ред. А. Н. Насонова: Москва-Ленинград, 1950).

НЛО -Новое литературное обозрение. Москва.

ПВЛ - Повесть временных лет, подг. текста, пер., ст. и комм. Д. С.

Лихачева. Под ред. В. П. Адриановой-Перетц. Изд. 2-е, подг. М. Б. Свердлов. Санкт-Петербург, 1996.

ПСРЛ, I-XLIII - Полное собрание русских летописей. T. I-XLIII.

Санкт-Петербург; Ленинград; Москва, 1841-2009.

РА - Российская археология. Москва.

ЯСК - Языки славянских культур. Москва.

100 В. Я. ПЕТРУХИН, РУСЬ в ІХ-Х в8. 238 и СЛ.

101 М. Б. Свердлов, Домонгольская Русь. Ср. о «моделях» феодализма: А. А. Горский, Средневековая Русь: о чем говорят источники (Москва: Ломоносовъ, 2021), 49-50. 


\section{References}

A. A. AMAL'RIK, Normanny i Kievskaia Rus', nauch. publikatsia, predislovie i kommentarii O. L. Gubareva [Normans and Kievan Rus, Scientific publication, foreword and comments by O. L. Gubarev] (Moskva: NLO, 2018).

A. K. AmBroz, "O Voznesenskom komplekse VIII v. na Dnepre - vopros interpretatsii" [About the Voznesensky Complex of the $8^{\text {th }}$ Century on the Dnieper - a Matter of Interpretation], v Drevnosti epokhi velikogo pereseleniia narodov V-VIII vV.: Sovetskovengerskii sbornik, red. A. K. AMBROZ, I. F. ERDELI (Moskva: Nauka, 1982), 204-221.

F. AndroshchuK, V. Zotsenko, Skandinavskie drevnosti iuzhnoi Rusi [Scandinavian Antiquities of southern Russia] (Paris: Institut arkheologii NAN Ukraini, 2012).

E. V. ANichkov, lazychestvo i Drevniaia Rus‘ [Paganism and Ancient Russia] (Moskva: Akademicheskii proekt, 2009).

M. V. Bıвıкоv, Byzantinorossica: Svod vizantiiskikh svidetel'stv o Rusi. I-IV. [Byzantinorossica: A Collection of Byzantine Testimonies about Rus. I-IV.] (Moskva: IASK, 2004-2020).

A. O. CHUBAR'IAN (pred.), Drevniaia Rus'i srednevekovaia Evropa: vozniknovenie gosudarstv, Materialy konferentsii [Ancient Russia and Medieval Europe: the Emergence of States, Conference Materials] (Moskva: In-t vseobshchei istorii RAN, 2012).

Dialog o knige: P. S. Stefanovich. Boiare, otroki, druzhiny: voenno-politicheskaia elita Rusi v X-XI vv. [Dialogue about the Book: P. S. Stefanovich. Boiars, Servants, Druzhinas: The Military-Political Elite of Russia in the X-XI Centuries], Rossiiskaia istoriia, no 6. (2014): 3-38.

L. DREGER, „Druzhina” [Druzhina] v Sotsial'no-ekonomicheskie otnosheniia i sotsionormativnaia kul'tura: Svod etnograficheskikh poniatii $i$ terminov [Socio-Economic Relations and Socionormative Culture: A Set of Ethnographic Concepts and Terms] red. A. I. PERShits, D. TRAIDE (Moskva: Nauka, 1986), 52-53.

A. IU. DVORNICHENKo, Zerkala i khimery. O vozniknovenii drevnerusskogo gosudarstva [Mirrors and Chimeras. On the Emergence of the Ancient Russian State] (Sankt-Peterburg; Moskva: Evraziia, 2014).

T. N. Dzhakson (red.), Drevniaia Rus' i srednevekovaia Evropa: vozniknovenie gosudarstv [Ancient Russia and Medieval Europe: the Emergence of States] (Moskva: In-t vseobshchei istorii RAN, 2016).

M. FASMER, Etimologicheskii slovar' russkogo iazyka [Etymological Dictionary of the Russian Language], per. i dopolneniia O. N. Trubacheva. V 4 t. T. III (Moskva: Progress, 1986).

A. V. Fedosov, Kristian Raffensperger, Korolevstvo Rus'. Drevniaia Rus' glazami zapadnykh istorikov [Kingdom of Russia. Ancient Russia Through the Eyes of Western Historians] (Moskva: Tsentrpoligrag, 2021).

B. N. FloRIA (red.), Khristianstvo v stranakh Vostochnoi, Iugo-Vostochnoi i Tsentral'noi Evropy na poroge vtorogo tysiacheletiia [Christianity in Eastern, Southeast and Central Europe on the Threshold of the Second Millennium] (Moskva: Indrik, 2002).

V. V. Fomın (sost.), Skandinavomaniia i ee nebylitsy o russkoi istorii [Scandinavian Mania and its Fables about Russian History] (Moskva: Russkaia panorama, 2015).

I. IA. Frolanov, Drevniaia Rus': opyt issledovaniia istorii sotsial'noi i politicheskoi bor'by [Ancient Rus: Experience in Researching the History of Social and Political Struggle] (Sankt-Peterburg, Moskva: Zlatoust, 1995). 


\section{В. Я. ПЕтРУХИН}

S. A. Gedeonov, Variagi i Rus' [Varangians and Russia] (Moskva: Russkaya panorama, 2004).

A. V. Gorovenko, Vasilii Tatishchev i "drevniie letopisi": domongol'skaia Rus' glazami pervogo russkogo istorika [Vasilii Tatishchev and the "Ancient Chronicles": the PreMongol Rus Through the Eyes of the First Russian historian] (Sankt-Peterburg: Izd-vo Olega Abyshko, 2019).

A. A. GoRSKII, Rus': ot slavianskogo Rasseleniia do Moskovskogo tsarstva [Russia: from Slavic Settlement to Muscovy] (Moskva: IASK, 2004).

A. A. GoRSKII, Russkoe srednevekovoe obshchestvo: istoriko-terminologicheskii spravochnik [Russian Medieval Society: a Historical and Terminological Reference Book] (Sankt-Peterburg: Izd-vo Olega Abyshko, 2019).

A. A. GoRSKII, Srednevekovaia Rus': o chem govoriat istochniki [Medieval Russia: What the Sources Say] (Moskva: Lomonosov", 2021).

A. A. Gorskil, V. A. Kuchkin, P. V. LUkin, P. S. Stefanovich, Drevniaia Rus': ocherki politicheskogo i sotsial'nogo stroia [Ancient Russia: Essays on the Political and Social System] (Moskva: Indrik, 2008).

V. L. IANIN, Denezhno-vesovye sistemy domongol'skoi Rusi i ocherki istorii dehenzhnoi sistemy srednevekovogo Novgoroda [Monetary and Weight Systems of Pre-Mongol Rus and essays on the History of the Monetary System of Medieval Novgorod] (Moskva: IASK, 2009).

V. L. IANIN, "O nachale Novgoroda" [On the Beginning of Novgorod] v $U$ istokov russkoi gosudarstvennosti, red. E. N. NosovA, A. E. MusınA (Sankt-Peterburg: Dmitrii Bulanin, 2007), 205-212.

E. V. Kamenetskaia, V. IA. Petrukhin, “Prussiia i Rus': srednevekovyi mif i noveishaia istoriografiia" [Prussia and Russia: Medieval Myth and Modern Historiography], Slavianovedeniie no. 5 (2008): 77-83.

A. V. KARAVASHKIN, Literaturnyi obychai Drevnei Rusi (XI-XVII vv.) [Literary Custom of Ancient Russia (XI-XVII centuries)] (Moskva, Sankt-Peterburg: Tsentr gumanitarnykh initsiativ, 2018).

M. KAZANSKI, A. NerCessian, C. ZuCKERMAN (eds.), Les centres proto-urbains Russes entre Scandinavie, Byzance et Orient [Russian Proto-Urban Centers Between Scandinavia, Byzantium and the East] (Paris: éditions P. Lerthielleux, 2000).

M. M. KAZANSKII, “O rasselenii slavian v lesnoi zone Vostochnoi Evropy: predmety rannesrednevekovogo ubora dunaiskogo proiskhozhdeniia (VI-IX vv.)" [On the Settlement of the Slavs in the Forest Zone of Eastern Europe: Items of Early Medieval Clothing of Danube Origin (VI-IX Centuries)], Arkheologicheskie Vesti 28 (2020): 258-271.

E. KHELIMSKII, “Tunguso-man'chzhurskii iazykovoi komponent v Avarskom kaganate i slavianskaia etimologiia [Tungus-Manchu Language Component in the Avar Kaganate and Slavic Etymology]" v Materialy $k$ dokladu na XIII Mezhdunarodnom s"ezde slavistov, Liubliana, 15-21 avgusta 2003 (Hamburg: Institut für Finnougristik/Uralistik, 2003).

A. N. KIRPICHNIKOV, V. D. SARAB'IANOV, Staraia Ladoga - pervaia stolitsa Rusi [Old Ladoga - the First Capital of Russia] (Sankt-Peterburg: Slaviia, 2013).

VALERI KIVEL'SON, Magiia otchaianiia: moral'naia ekonomika koldovstva v Rossii XVII veka [The Magic of Despair: The Moral Economy of Witchcraft in $17^{\text {th }}$ Century Russia] per. s angl. V. Petrov (SPb.: Academic Studies Press/ BiblioRossika, 2020).

L. S. KLEIN, Spor o variagakh: istoria protivostoiania i argumenty storon [Dispute about 
the Varangians: the History of the Confrontation and the Arguments of the Parties] (Sankt-Peterburg: Evraziia, 2009).

V. B. KoBRIN, Komu ty opasen, istorik? [To Whom Are You Dangerous, Historian?] (Moskva: Moskovskii rabochii, 1992).

B. S. Korotkevich, D. A. Machinskil, T. B. Senichenkova (redkoll.), Slozhenie russkoi gosudarstvennosti $v$ kontekste rannesrednevekovoi istorii Starogo Sveta: materialy Mezhdunarodnoi konferentsii, sostoiavsheisia 14-18 maia 2007 g. v Gosudarstvennom Ermitazhe [The Formation of Russian Statehood in the Context of the Early Medieval History of the Old World: Materials of the International Conference held on May 14-18, 2007 in the State Hermitage] (Sankt-Peterburg: Gos. Ermitazh, 2009).

M. M. KROM (red.), Spory o novgorodskom veche: mezhdistsiplinarnyi dialog [Disputes about the Novgorod Veche: an Interdisciplinary Dialogue] (Sankt-Peterburg: Evropeiskii universitet, 2012).

V. S. KULESHOV, "K otsenke dostovernosti etimologii slova Rus"' [To Assessing the Reliability of Etymologies of the Word Rus] v Slozhenie russkoi gosudarstvennosti v kontekste rannesrednevekovoi istorii Starogo sveta. Materialy mezhdunarodnoi konferentsii. Trudy GE. Vyp. XLVIII. (Sankt-Peterburg: Izdatel'stvo Gosudarstvennogo Ermitazha, 2009), 439-457. A. G. Kuz'Min, M. IU. LACHAEVA, N. M. Rogozhin, Istoriografiia istorii Rossii do 1917 goda [Historiography of the History of Russia Before 1917] (Moskva: Vlados, 2004).

N. A. Krenke, I. N. ERShov, V. A. Raeva, "Smolensk i Gnezdovo" [Smolensk and Gnezdovo], Arkheologicheskie vesti 28 (2020): 296-303.

G. S. LEBEDEV, „Kommentarii k stat'e I Russkoi pravdy Kratkoi redaktsii [Commentary on Article I of Russkaya Pravda of the Short Edition]" v Genezis i razvitie feodalizma v Rossii. Vyp. 10, red. I. IA. FroIAnov (Leningrad: izd-vo LGU, 1987), 78-84.

G. G. LITAVRIN (Tekst, perevod i vstupitel'naia stat'ia), Konstantin Bagrianorodnyi. Ob upravlenii imperiei [Constantine Porphyrogenitus. On the Governance of the Empire] Izd. 2-e (Moskva: Nauka, 1991).

A. F. LITVINA, F. B. USPENKII, Vybor imeni u russkikh kniazei v X-XVI vv. [The Choice of Names Among Russian Princes in the X-XVI Centuries] (Moskva: Indrik, 2006).

G. LOVMIAN‘SKII, “Russy i rugi” [Russ and Rugi], Voprosy Istorii no. 9 (1971): 43-52.

P. V. LUKIN, Novgorodskoe veche [Novgorod Veche] (Moskva: Indrik, 2014).

N. A. MAKARov (red.), Rus' v IX-X vV.: arkheologicheskaia panorama [Russia in the $9^{\text {th }}$ $10^{\text {th }}$ Centuries: an Archaeological Panorama] (Moskva; Vologda: Drevnosti Severa, 2012). N. A. Makarov, A. V. NazArenko (red.), Rus' epokhi Vladimira Velikogo: gosudarstvo, tserkov, kul'tura [Russia in the Era of Vladimir the Great: State, Church, Culture] (Moskva: Drevnosti Severa, 2017).

N. A. MAKAROV, E. N. Nosov, V. L. IANIN, “Nachalo Rusi glazami sovremennoi arkheologii” [The Beginning of Russia through the Eyes of Modern Archeology] v Trudy otdeleniia istoriko-filologicheskikh nauk RAN (Moskva: Nauka, 2014), 17-36.

K. A. MAKsIMOvich, Proiskhozhdenie etnonima Rus' $v$ svete istoricheskoi lingvistiki i drevneishikh pis‘mennykh istochnikov, v KANIEKION. Iubileinyi sbornik v chest 60 -letiia professora Igoria Sergeievicha Chichurova [The Origin of the Ethnonym Rus in the Light of Historical Linguistics and the Oldest Written Sources, v KANIEKION. Jubilee Collection in Honor of the $60^{\text {th }}$ Anniversary of Professor Igor Sergeevich Chichurov] (Moskva: Pravoslavnyi Sviato-Tikhonovskii gumanitarnyi universitet, 2006).

E. A. MEL'NIKOVA, “Renessans Srednevekov'ia? Razmyshlenia o mifotvorchestve v sovre- 
mennoi istoricheskoi nauke" [Renaissance of the Middle Ages? Reflections on Mythmaking in Modern Historical Science], Rodina, no. 3 (2009): 56-58. i Rodina, no. 5 (2009): 55-57. E. A. Mel'Nikova, V. IA. Petrukhin (red.), Drevniaia Rus'v srednevekovom mire. Entsiklopediia [Ancient Russia in the Medieval World. Encyclopedia] (Moskva: Ladomir, 2014).

E. A. Mel'Nikova, V. IA. Petrukhin, “Nazvanie 'Rus'” v etnokul'turnoi istorii Drevnerusskogo gosudarstva" [The Name of Rus' in ethno-cultural history of the Old Russian State], Voprosy Istorii no. 8 (1989): 24-38.

K. A. MIKHAILov, Elitarnyi pogrebal'nyi obriad Drevnei Rusi [Elite Funeral Rite of Ancient Russia] (Sankt-Petersburg: Izdatel'skii dom Branko, 2016).

L. V. MiLov, "Ruzzi 'Bavarskogo geografa' i tak nazyvaemye 'rusichi”" [Ruzzi "Bavarian Geographer" and the so-called "rusichi"], Otechestvennaia istoriia no. 1 (2000): 94-101.

L. A. MosıonzHNIK, Tekhnologiia istoricheskogo mifa [The Technology of Historical Myth] (Sankt-Peterburg: Nestor-Istoriia, 2012).

V. V. Murasheva, S. IU. Kainov, Vikingi. Put‘ na Vostok [Vikings. The Road to East] (Moskva: GIM, 2020).

V. V. Murasheva, A. V. Panin, A. O. Shevtsov, N. N. Malysheva, E. P. Zazovskaia, N. E. ZARETSKAIA, "Vremia vozniknoveniia poseleniia Gnezdovskogo arkheologicheskogo kompleksa po dannym radiouglerodnogo datirovaniia" [The Time of the Emergence of the Settlement of the Gnezdovsky Archaeological Complex According to Radiocarbon Dating], Rossiiskaia arkheologiia no. 4 (2020): 70-86.

A. V. NAZARENKo, "Ob imeni "rus'” v nemetskikh istochnikakh IX-XI vv." [About the Name "Rus" in German Sources of the $9^{\text {th }}-11^{\text {th }}$ Centuries], Voprosy iazykoznaniia no. 5 (1980): 40-56.

V. A. NAzARenko, "Mogil'nik v urochishche Plakun [Burial Ground in the Plakun Tract]" v Srednevekovaia Ladoga, red. V. V. SEdov (L.: Nauka, 1985) 156-169.

LIUBOR NIDERLE, Slavianskie drevnosti [Slavic Antiquities], per. s cheshsk. T. KovalevoI, M. KHAZANOVA (Moskva: izd-vo inostrannoy literatury, 1956).

T. E. NovitSKAIA (red.), "Istoricheskoe pravovedenie". Vyn. 5: Tysiacheletie Pravdy Russkoi: istoria $i$ perspektivy izucheniia drevneishego pamiatnika otechestvennogo prava: $c b$. nauchnykh trudov ["Historical jurisprudence". Issue 5: Millennium of Russian Truth: History and Prospects of Studying the Most Ancient Monument of Russian Law: Collection of Articles. Scientific Papers] (Sankt-Peterburg: Prezidentskaia biblioteka, 2017).

A. M. ОвцомSKII, "Struktura naseleniia lesostepnogo Podneprov'ia v VII v. n. e." [The Structure of the Population of the Forest-steppe Dnieper region in the $7^{\text {th }}$ century], $v$ DG 2010 god: Predposylki i puti obrazovaniia Drevnerusskogo gosudarstva, red. E. A. MEL‘Nikova (Moskva: Un-t Dmitriia Pozharskogo, 2012), 10-33.

V. T. PAShuto, L. V. Cherepnin (red.), Drevnerusskoe gosudarstvo i ego mezhdunarodnoe znachenie [Old Russian State and its International Significance] (Moskva: Nauka, 1965).

A. I. Pershits, D. TRAIDE (red.), Sotsial'no-ekonomicheskie otnosheniia i sotsionormativnaia kul'tura: Svod etnograficheskikh poniatii i terminov [Socio-Economic Relations and Socionormative Culture: A Set of Ethnographic Concepts and Terms] (Moskva: Nauka, 1986).

V. IA. Petruknin, Drevniaia Rus'. Narod. Kniaz'ia. Religiia. Iz istorii russkoi kul'tury. T. 1. [Ancient Russia. People. Princes. Religion, From the history of Russian culture. T. 1] (Moskva: lazyki russkoi kul'tury, 2000).

V. IA. Petrukhin, "K istorii davnei diskussii: Smolensk i Gnezdovo" [On the History of 
a Long-standing Discussion: Smolensk and Gnezdovo], v Gnezdovskii arkheologicheskii kompleks: Materialy i issledovaniia. Vyp. 1, Trudy GIM, Vyp. 210., red. S. IU. KAINov (Moskva: GIM, 2018), 462-473.

V. IA. Petrukhin, "Khazarskoe nachalo russkoi istorii" [Khazar Beginning of Russian History] v Polystoria. Zodchie, konungi, pontifiki v srednevekovoi Evrope, red. A. M. BoITSOV, O. V. VosковолNIKov. 2-nd ed. (Moskva: Vyshaia shkola ekonomiki, 2021), 43-86. V. IA. PEtRUKhIN, "Prizvanie variagov: traditsiia i istoricheskie realii" [Vocation of Varangians: Tradition and Historical Realities] v Trudy otdeleniia istoriko-filologicheskikh nauk RAN (Moskva: Nauka, 2014), 289-299.

V. IA. Petrukhin, Rus' khristianskaia i iazycheskaia: Istoriko-arkheologicheskie ocherki [Christian and Pagan Rus: Historical and Archaeological Essays] (Sankt-Peterburg: Izd-vo Olega Abyshko), 2019).

V. IA. PETRUKHIN, Rus' V IX-X vV.: ot prizvaniia variagov do vybora very [Russia in the $9^{\text {th }}-10^{\text {th }}$ Centuries: From the Vocation of the Varangians to the Choice of Faith] (3-d ed. Moskva: Neolit/Forum, 2017).

V. IA. Petrukhin, "V. L. Ianin i prizvanie variagov" [V. L. Ianin and the Vocation of the Varangians], Novgorodskii Istoricheskii Sbornik 19 (29) (2020): 29-37.

V. IA. PETRUKhIN, “V. T. Pashuto o drevnerusskoi praktike riada [V.T. Pashuto on the Ancient Russian Practice of ryad]" v DG 2019-2020 gody: Diplomaticheskie praktiki Antichnosti i Srednevekov'ia (Moskva: Un-t Dmitriia Pozharskogo, 2020), 42-50.

V. IA. Petrukhin, "Veshchii Oleg i "mogila v Ladoge" [Prophetic Oleg and „the grave in Ladoga"] v Zemlia nasha velika i obil'na: sb. statei posviashchennyi 90-letiiu A. N. Kirpichnikova, red. S. V. BELETSKII (Sankt-Peterburg: Knizhnaia tipografiia, 2019), 302-331. V. IA. Petrukhin, T. A. Pushkina, "K predystorii drevnerusskogo goroda" [To the Prehistory of the Ancient Russian City], Istoriia SSSR no. 4 (1979): 100-112.

N. I. Platonova, “Drevnerusskaia kul'tura i drevnerusskaia elita: problemy i perspektivy issledovanii [Old Russian Culture and Old Russian Elite: Problems and Research Prospects]" v Élite ou Égalité... Severnaia Rus' i kul'turnye transformatsii v Evrope VII-XII vv., red. N. I. Platonova (Sankt-Peterburg: Izdatel'skii dom «Branko», 2017), 9-29.

T. A. Pushikina, V. V. Murasheva, N. V. EnIosova, "Gnezdovskii arkheologicheskii kompleks" [Gnezdovskii Archaeological Complex] v Rus' v IX-IX vv. Arkheologicheskaia panorama, red. N. A. MAKARov (Moskva, Vologda: Drevnosti Severa, 2012), 242-273.

V. V. PuzAnov, "Khimery v krivom zerkale istoriografii" [Chimeras in the Distorting Mirror of Historiography], Vestnik SPbGU. Istoria 62, no. 2 (2017): 418-432.

V. V. PuzAnov, Ot praslavian $k$ Rusi: stanovlenie Drevnerusskogo gosudarstva (faktory $i$ obrazy politogeneza) [From the Proto-Slavs to Russia: The Formation of the Old Russian State (Factors and Images of Political Genesis)] (Sankt-Peterburg: Izd-vo Olega Abyshko, 2017).

T. V. ROZHDESTVENSKAIA, Drevnerusskaia epigrafika X-XV vv. [Old Russian Epigraphy of the $10^{\text {th }}-15^{\text {th }}$ Centuries] (Sankt-Peterburg: SPbGU, 1991).

V. V. SEdov, Slaviane: istoriko-arkheologicheskoe issledovanie [Slavs: Historical and Archaeological Research] (Moskva: IASK, 2002).

A. S. ShCHAVELEV, Khronotop derzhavy Riurikovichei (911-987 gody) [Chronotope of the State of Rurikovich] (Moskva: Akvilon, 2020).

O. A. ShCheglova, "Volny rasprostraneniia veshchei iz Podunav'ia: otrazhenie 


\section{В. Я. ПЕтрухин}

slavianskoi migratsii ili kul'turnykh infil'tratsii?" [Waves of the Spread of Things from the Danube: a Reflection of Slavic Migration or Cultural Infiltrations?], v Slozhenie russkoi gosudarstvennosti $v$ kontekste rannesrednevekovoi istorii Starogo sveta. Materialy mezhdunarodnoi konferentsii. Trudy GE. Vyp. XLVIII. (Sankt-Peterburg: Izdatel'stvo Gosudarstvennogo Ermitazha, 2009), 39-65.

E. A. Shinakov, Obrazovanie Drevnerusskogo gosudarstva. Sravnitel'no-istoricheskii aspekt [The Formation of the Old Russian State. Comparative Historical Aspect] (Moskva: Vost. lit. 2009).

V. A. SHNIREL'MAN, Khazarskii mif: Ideologia politicheskogo radikalizma v Rossii i ee istoki [Khazar Myth: The Ideology of Political Radicalism in Russia and Its Origins] (Moskva: Mosty kultury/Gesharim, 2010).

M. B. SHUkIn, Gotskii put' [Gothic Way] (Sankt-Peterburg: Filologicheskii fakul'tet SPbGU, 2005).

S. V. SoKolov, Kontseptsii proiskhozhdeniia variazhskoi rusi v rossiiskoi istoriografii XVIII-XIX vv. v kontekste evropeiskikh idei rannego novogo vremeni [Concepts of the Origin of Varangian Rus in Russian Historiography of the $18^{\text {th }}-19^{\text {th }}$ Centuries in the Context of Early Modern European Ideas] (Ekaterinburg: Bank kul'tornoi informatsii, 2015).

K. A. Solov'EV, Delo vlasti: otechestvennye istoriki o vlastnykh otnosheniiakh v Drevnei $i$ Srednevekovoi Rusi (IX-perv. pol. XV vv.) [The Case of Power: Russian Historians on Power Relations in Ancient and Medieval Russia (IX - First Half of the XV Centuries)] (Moskva: MAKS Press, 2001).

P. S. Stefanovich, Boiare, otroki, druzhiny: voenno-politicheskaia elita Rusi v X-XI vekakh [Boiars, Servants, Druzhinas: The Military-Political Elite of Russia in the X-XI Centuries] (Moskva: Indrik, 2012).

Adol'F Stender-Petersen, Varangika: istoriko-filologicheskie issledovaniia red. E. A. Melnikova [Varangika; Historical and Philological Studies] (Moskva: Varfolomeev, 2021).

M. B. SVERDLov, Domongol'skaia Rus': kniaz' i kniazheskaia vlast' na Rusi VI - pervoi treti XIII v. [Pre-Mongol Russia: The Prince and Princely Power in Russia in the $6^{\text {th }}-$ First Third of the $13^{\text {th }}$ Century] (Sankt-Peterburg: Akademicheskii proekt, 2003).

M. B. SVERDLov, Latinoiazychnye istochniki po istorii Drevnei Rusi IX-XVIII vv. Germania. "Pravda Russkaia”. Istoria teksta. Izbrannye stat'i [Latin-language Sources on the History of Ancient Russia in the $9^{\text {th }}-13^{\text {th }}$ Centuries. Germany. "Russkaia Pravda“. History of the text. Featured Articles] (Sankt-Peterburg: Izd-vo Olega Abyshko, 2017).

B. A. Timoshuk, Vostochnye slaviane: ot obshchiny $k$ gorodam [Eastern Slavs: From Commune to Cities] (Moskva: izd-vo Mosck. un-ta, 1995).

S. R. TOKHTAS`EV, lazyk traktata Konstantina Bagrianorodnogo De administrando Imperio i ego inoiazychnaia leksika [The Language of the Treatise of Constantine Porphyrogenitus De administrando Imperio and its Foreign Language Vocabulary] (SPb: Nauka, 2018).

A. P. Tolochко, "Istoriia Rossiiskaia" Vasiliia Tatishcheva: istochniki i izvestiia ["Russian History" by Vasilii Tatishchev: sources and news] (Moskva, Kiyev: NLO, 2005).

A. P. Tоцоснко, Ocherki nachal'noi rusi [Essays on Primary Rus'] (Kiev: Sankt-Peterburg: Laurus, 2015).

V. TOMSEn, "Nachalo Russkogo gosudarstva" [Beginning of the Russian State], v Iz istorii russkoi kul'tury, T. II, sost. A. F. LITVINA, F. B. USPENSKII (Moskva: IASK, 2002).

B. Totev, O. Pelevina, "Sokrovishche iz Maloi Pereshchepiny i elitarnaia kul'tura bolgar Nizhnego Dunaia" [Treasure from Mala Pereshchepina and the Elite Culture of the 
Bulgarians of the Lower Danube] v Forum "Idel' - Altai". Seriia "Arkheologiia evraziiskikh stepei”. Vyp. 13 (Kazan': Institut istorii AN RT, 2010), 174-179.

O. N. TRUBAChev (red.), Etimologicheskii slovar' slavianskikh iazykov [Etymological Dictionary of Slavic Languages] Vyp. 13 (Moskva: Nauka, 1987).

Konstantin Tsukerman, "Perestroika drevneishei russkoi istorii" [Restructuring of the Oldest Russian History], v U istokov russkoi gosudarstvennosti, red. E. N. NosovA, A. E. MusinA (Sankt-Peterburg: Dmitrii Bulanin, 2007), 334-351.

D. N. VerkHoturov, Tri veka spora o variagakh. Letopis' i variagi [Three Centuries of Dispute about the Varangians. Chronicle and Varangians] (Moskva: Veche, 2020).

G. V. VERNADSKII, Drevniaia Rus' [Ancient Russia] (Moskva: Lomonosov, 2017).

T. L. VILKUL, Letopis' i khronograf: Tekstologiia domongol'skogo kievskogo letopisaniia [Chronicle and Chronograph: Textology of the Pre-Mongol Kiev Chronicle] (Moskva: Kvadriga, 2019).

T. L. VILKUL, Liudi i kniaz' v drevnerusskikh letopisiakh serediny XI-XIII vv. [People and the Prince in the Old Russian Chronicles of the mid- $11^{\text {th }}-13^{\text {th }}$ Centuries] (Moskva: Kvadriga, 2009).

V. G. VovinA-LeBedeVA, Shkoly issledovaniia russkikh letopisei: XIX-XX vv. [Schools for the Study of Russian Chronicles: XIX-XX centuries] (Sankt-Peterburg: Dmitrii Bulanin, 2011).

A. A. ZALIZNIAK, Slovo o polku Igoreve: vzgliad lingvista [Tale of Igor's Campaign: A Linguist's Point of View] (Moskva: IASK, 2008).

A. A. Zımın, Pravda Russkaia [Russkaia Pravda] (Moskva: Drevlekhranilishche, 1999).

A. A. Zımın, Slovo o polku Igoreve [Tale of Igor's Campaign] (Sankt-Peterburg, 2006).

M. O. ZHUKovSKII, "Srednevekovye vesovye gir'ki s podrazhaniiami arabskim nadpisiam" [Medieval Weights with Imitations of Arabic Inscriptions], Povolzhskaia arkheologiia 26, no. 4 (2018): 117-126. DOI: 10.24852/2018.4.26.117.136

D. V. ZHURAVLEV, V. V. MURASHEVA (sost.) Mech i zlatnik: $k$ 1150-letiiu zarozhdeniia Drevnerusskogo gosudarstva [The Sword and the Goldsmith: to the $1150^{\text {th }}$ Anniversary of the Birth of the Old Russian State] (Moskva: GIM, 2012). 